\title{
ASSESSING CONTROLS ON ICE DYNAMICS AT CRANE GLACIER, ANTARCTIC PENINSULA USING A NUMERICAL ICE FLOW MODEL
}

by

Rainey Aberle

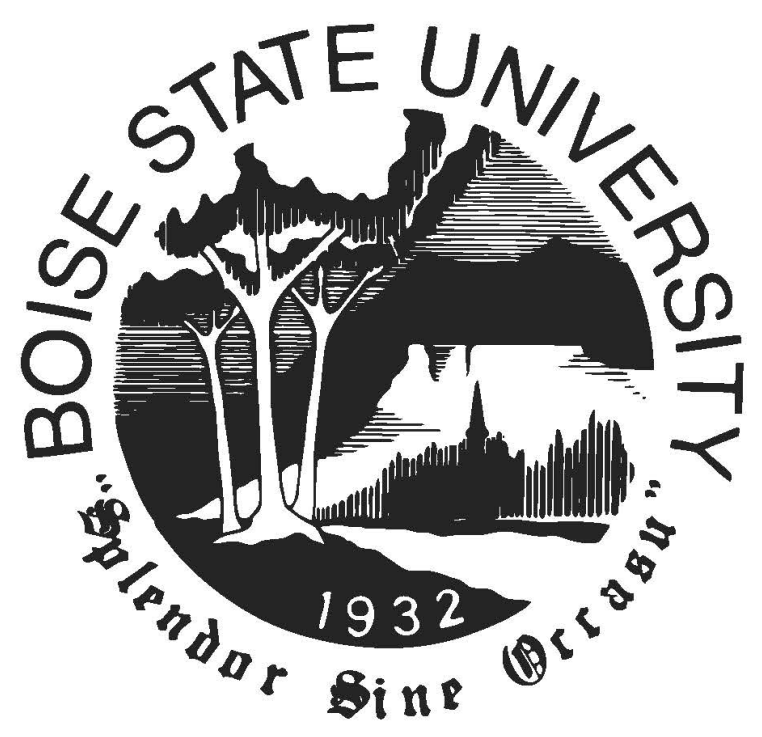

A thesis

submitted in partial fulfillment

of the requirements for the degree of

Master of Science in Geophysics

Boise State University

August 2021 
(C) 2021

Rainey Aberle

ALL RIGHTS RESERVED 
BOISE STATE UNIVERSITY GRADUATE COLLEGE

\title{
DEFENSE COMMITTEE AND FINAL READING APPROVALS
}

of the thesis submitted by

\author{
Rainey Aberle
}

Thesis Title: Assessing Controls on Ice Dynamics at Crane Glacier, Antarctic Peninsula Using a Numerical Ice Flow Model

Date of Final Oral Examination: 30 April 2021

The following individuals read and discussed the dissertation submitted by student Rainey Aberle, and they evaluated the student's presentation and response to questions during the final oral examination. They found that the student passed the final oral examination.

Ellyn Enderlin, Ph.D.

Hans-Peter Marshall, Ph.D.

Michal Kopera, Ph.D.
Chair, Supervisory Committee

Member, Supervisory Committee

Member, Supervisory Committee

The final reading approval of the thesis was granted by Ellyn Enderlin, Ph.D., Chair of the Supervisory Committee. The thesis was approved by the Graduate College. 


\section{DEDICATION}

To my friend, my queen, my cat Cleopatra. 


\section{ACKNOWLEDGMENT}

This research is funded by NSF Grant 1933764. Many thanks to my committee members Dr. Enderlin, Dr. Marshall, and Dr. Kopera for their support and expertise that aided this work. I also owe thanks to Tate Meehan for his assistance with the radar interpretation which helped to provide a bed elevation profile, as well as the rest of the CryoGARS lab at Boise State University for their time, support, and feedback throughout this project. Finally, I owe this work to my friends, family, and loved ones for their love and care that helped me along the way. 


\section{AUTOBIOGRAPHICAL SKETCH}

I was born near Seattle, WA, then moved north to Bellingham, WA after spending a few years on the east coast. In 2013, I graduated from Sehome High School as class valedictorian and began attending Pacific Lutheran University in Tacoma, WA as an intended physics major. During my sophomore year, I discovered my interest in the geosciences and spent a semester abroad studying topics in social justice and climate change at the University of Oxford. After returning to Tacoma, I was able to spend a summer researching at Mt. Rainier National Park with colleagues under Dr. Claire Todd, where I fostered a love for glacier research, remote sensing, and field work. In 2017, I completed my B.S. in Geosciences and B.A. in Physics, graduating with honors. After completing an exciting volcanology field camp in Iceland, I spent a year serving with the Washington Conservation Corps, where I built skills in habitat restoration and surveying, particularly for indicators of salmon habitat health. The following year, I served as an AmeriCorps Food Educator with Common Threads, where I taught cooking and gardening classes to elementary school students in their

school gardens. In 2019, I accepted the offer to work under Dr. Ellyn Enderlin's advisory at Boise State University to continue my education in glaciology and geophysics. Here, I have taken courses related to the geosciences, geophysics, and remote sensing, as well as collaborated with colleagues on interdisciplinary research projects which have supported this work. 


\section{ABSTRACT}

The widespread retreat of glaciers and the collapse of ice shelves along the Antarctic Peninsula has been attributed to atmospheric and oceanic warming, which promotes mass loss. However, several glaciers on the eastern peninsula that were buttressed by the Larsen A and B ice shelves prior to collapse in 1995 and 2002, respectively, have been advancing in recent years. This asymmetric pattern of rapid retreat and long-term re-advance is similar to the tidewater glacier cycle, which can occur largely independent of climate forcing. Here, I use a width- and depth-integrated numerical ice flow model to investigate glacier response to ice shelf collapse and the influence of changing climate conditions at Crane Glacier, formerly a tributary of the Larsen B ice shelf, over the last $\sim 10$ years. Sensitivity tests to explore the influence of perturbations in surface mass balance and submarine melt (up to $10 \mathrm{~m} \mathrm{a}^{-1}$ ) and fresh water impounded in crevasses (up to $10 \mathrm{~m}$ ) on glacier dynamics reveal that by 2100 , the modeled mass discharge ranges from $0.53-98 \mathrm{Gt} \mathrm{a}^{-1}$, with the most substantial changes due to surface melt-induced thinning. My findings suggest that the growth of a floating ice tongue can hinder enhanced flow, allowing the grounding zone to remain steady for many decades, analogous to the advancing stage of the tidewater glacier cycle. Additionally, former tributary glaciers can take several decades to geometrically adjust to ice shelf collapse at their terminal boundary while elevated glacier discharge persists. 


\section{TABLE OF CONTENTS}

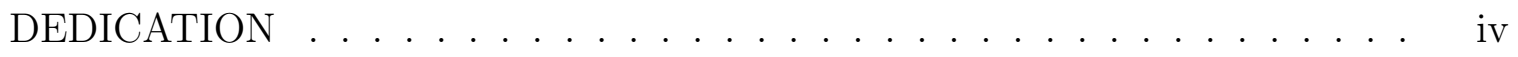

ACKNOWLEDGMENT . . . . . . . . . . . . . . . . . v v

AUTOBIOGRAPHICAL SKETCH ................ . . vi

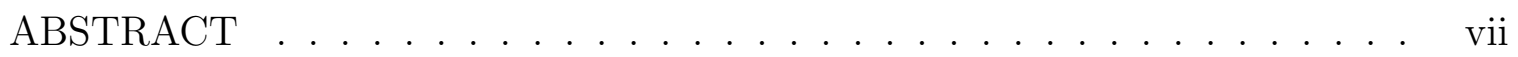

LIST OF FIGURES . . . . . . . . . . . . . . . . . .

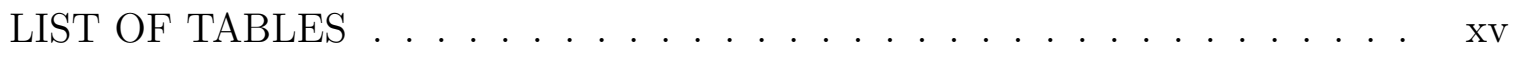

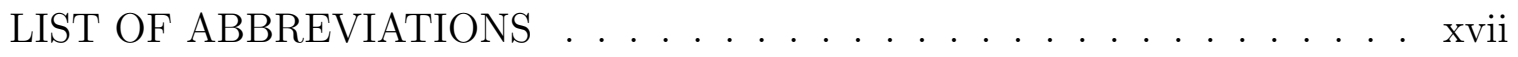

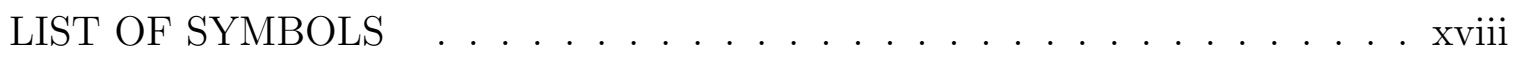

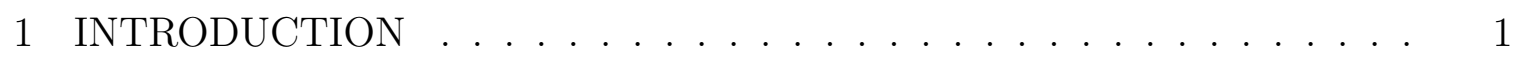

2 BACKGROUND . . . . . . . . . . . . . . . . . . . 6

2.1 Ice dynamics . . . . . . . . . . . . . . . . 6

2.2 Antarctic Peninsula Environmental Change . . . . . . . . . . . . . . 10

2.3 Flowline Model . . . . . . . . . . . . . . . . . . . . . 11 


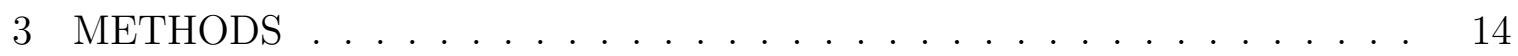

3.1 Glacier Geometry Observations . . . . . . . . . . . . . . . 14

3.2 Boundary Fluxes . . . . . . . . . . . . . . . . . . . 17

3.3 Model Initialization . . . . . . . . . . . . . . . . . . . 23

3.4 Model Sensitivity Tests . . . . . . . . . . . . . . . 27

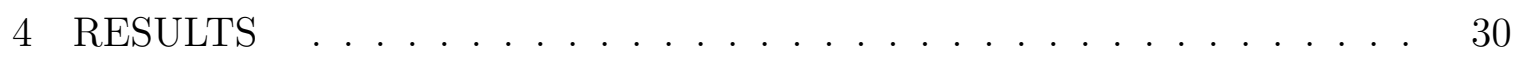

4.1 Submarine Melt Rate . . . . . . . . . . . . . . . . . . 30

4.2 Surface Mass Balance . . . . . . . . . . . . . . . . . . 33

4.3 Fresh Water in Crevasses . . . . . . . . . . . . . . . . 34

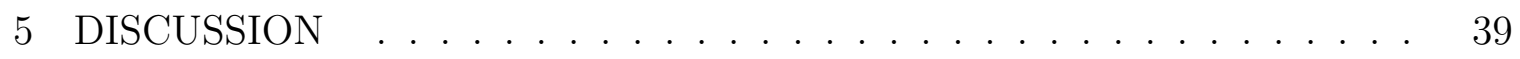

5.1 Model Response to Climate Perturbations . . . . . . . . . . . . 39

5.2 Glacier Response to Ice Shelf Collapse . . . . . . . . . . . . . . . . . 41

5.3 Potential Biases . . . . . . . . . . . . . . . . . 43

5.4 Conclusions and Future Work . . . . . . . . . . . . . . . . 44

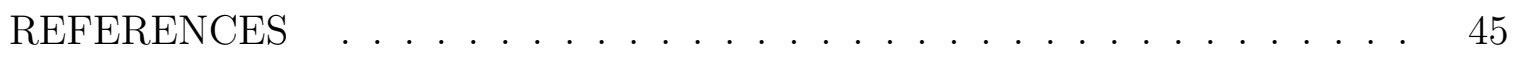




\section{LIST OF FIGURES}

1.1 Map view of 2014-2021 terminus time series for former Larsen A ice shelf tributaries: (a) Edgeworth and (b) Drygalski Glaciers, and former Larsen B ice shelf tributaries: (c) Hektoria and Green, (d) Jorum, and (e) Crane Glaciers, colored by year. Black arrows indicate flow direction. Terminus positions are delineated using the Google Earth Engine Digitisation Tool (GEEDiT) and Margin change Quantification Tool (MaQiT) (Lea, 2018). Background images are from the panchromatic band of Landsat 8 imagery captured 10 January and 15 October 2020. The regional map (upper left) is the Landsat Image Mosaic of Antarctica with respective glacier locations marked. . . . . . . . . . 2 
1.2 (a) Map of Crane Glacier, eastern Antarctic Peninsula. Labeled are the manually delineated glacier centerline where conditions are modeled with $10 \mathrm{~km}$ increments marked, NASA Operation IceBridge (Operation IceBridge (OIB)) flight paths, and surface speeds from 2017 NASA ITS_LIVE. Elevation contours are from the Reference Elevation Model of Antarctica in meters above sea level (Howat et al., 2019). Background image is the panchromatic band of Landsat 8 imagery captured 10 January 2020. Inset plot is the Landsat Image Mosaic of Antarctica with the study region circled (yellow). Adjacent glaciers and tributaries A, B, and C are labeled. (b) Near infrared band of the same Landsat image slightly zoomed in to lower elevations with visible melt water in pools and crevasses on the Crane Glacier surface. . . . . .

2.1 Modified from Shepherd et al. (2018). Diagram demonstrating glacier dynamics including ice shelf buttressing, external forcings, and stresses within the ice represented in Equation 2.2, where $\tau_{\text {lon }}$ is the longitudinal stress, $\tau_{l a t}$ is the lateral resistance, and $\tau_{b}$ is the basal resistance. . . .

2.2 Modeled glacier geometry through a tidewater glacier cycle from Brinkerhoff et al. (2017). The panels are not uniformly distributed in time due to the asymmetric time scales of advance and retreat. In phase one, the glacier is retracted, then advances until $t=286$ years. At $t=306$ years, fluvial erosion thins the shoal's upstream end causing the glacier to come afloat. The beginning of this process is evident in the small void developing at the upstream end of the shoal. Over the next 20 years, the glacier retreats towards its initial state. . . . . . . . 
3.1 (a) Map view of the glacier extent polygon used to clip line segments perpendicular to the glacier centerline, creating width segments. The background image is a Landsat 8 panchromatic image from 13 October 2019. (b) The glacier width profile. . . . . . . . . . . . . . . .

3.2 Time series of glacier centerline observations for (a) surface elevations, the radar- and sonar-derived bed elevation profile $b$ (dashed line), the width-averaged bed elevation profile $b_{\mu}$ (solid line), (b) width-averaged surface speeds, and (c) modeled surface mass balance (SMB) statistically downscaled from Regional Atmospheric Climate Model v. 2.3 (RACMO2.3) using methods described by Noël et al. (2016), with the time-averaged surface mass balance (SMB) for 2009-2019 indicated by the black line. Colors of lines indicate the date of observation, shown in the color bar (right). Dashed vertical lines in panel (a) represent the estimated terminus positions from (Dryak \& Enderlin, 2020) corresponding to the surface elevation observation date. . . . . . . .

3.3 Average annual strain profiles estimated using centerline observations of speed for 2008-2018 (left y-axis) and the temperature-dependent rate factor, $A$, adjusted using the average strain profile, $A_{a d j}$ (right y-axis). 
3.4 Model misfits calculated with respect to 2018 observed conditions resulting from the model run of 2009-2018 using all tuned parameters. (a) The surface elevation misfit and (b) the surface speed misfit. (c) $h_{\text {mod }}$ and $h_{o b s}$ are the modeled and observed 2018 surface elevation along the profile and (d) $U_{m o d}$ and $U_{o b s}$ are the modeled and observed 2018 speed, respectively. The dashed lines in panels (a) and (b) represent the average 2018 misfit along the centerline. . . . . . . . . . . . .

4.1 Results of model sensitivity tests in year 2100 for (first column) the submarine melt rate $(\Delta$ submarine melting rate $(\mathrm{SMR}))$, (second column) the surface mass balance $(\triangle \mathrm{SMB})$, and (third column) the fresh water depth in crevasses $\left(\Delta d_{f w}\right)$. (a-c) The resulting glacier geometry, (d-f) thickness, (g-i) speed, and (j-l) changes in grounding line (crosses) and calving front positions (circles) are shown with respect to the unperturbed scenario, shown in dark purple. Note that warmer colors indicate increased melting, positive $\Delta \mathrm{SMR}$ and $\Delta d_{f w}$ values indicate increased melting, and positive $\Delta \mathrm{SMB}$ values indicate decreased melting or increased accumulation. . . . . . . . . . . . .

4.2 Glacier mass discharge across the grounding line $\left(F_{g l}\right)$ in model year 2100 resulting from each of the perturbation scenarios. $F_{g l}$ from each scenario is plotted for a) maximum submarine melt rate $\left(S M R_{\max }\right)$, b) mean surface mass balance $\left(S M B_{\text {mean }}\right)$, and c) fresh water depth in crevasses $\left(d_{f w}\right)$. Colors represent the change in each variable with respect to the unperturbed scenario, where warmer colors signify higher melt scenarios. . . . . . . . . . . . . . . . 
4.3 Time series of Crane Glacier observed and modeled calving front position along the centerline (black) and mass discharge across the grounding line (red). Observed discharge estimates (red crosses) are from Rignot et al. (2004) and observed calving front positions (black crosses) are from Dryak \& Enderlin (2020). Different climate perturbation scenarios are distinguished by line type, including the unperturbed scenario and the maximum melt scenarios for the submarine melt $(\Delta \mathrm{SMR}=$ $\left.+10 \mathrm{~m} \mathrm{a}^{-1}\right)$, the surface mass balance $\left(\Delta \mathrm{SMB}=-10 \mathrm{~m} \mathrm{a}^{-1}\right)$, and calving due to hydrofracturing $\left(\Delta d_{f w}=+10 \mathrm{~m}\right)$, averaged over one-year

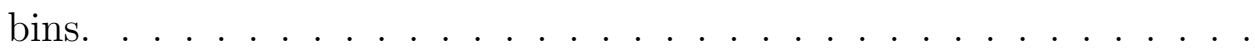




\section{LIST OF TABLES}

2.1 Model Constants . . . . . . . . . . . . . . . . .

3.1 Datasets employed for time series of glacier surface elevation, bed elevation, surface speed, modeled surface mass balance, and terminus positions with corresponding spatial resolution, temporal coverage, and mean reported error. . . . . . . . . . . . . . . . . .

4.1 Results for the submarine melt sensitivity tests at the final model year 2100 , where $\Delta$ SMR is the maximum submarine melt perturbation with respect to the unperturbed scenario, $\Delta L$ is the change in modeled glacier length, $\Delta x_{g l}$ is change in the grounding line position along the centerline, and $\Delta H_{g l}, \Delta U_{g l}$, and $F_{g l}$ are the glacier thickness, speed, and mass discharge at the grounding line, respectively. . . . . . . .

4.2 Results for the surface mass balance sensitivity tests at the final model year 2100, where $\Delta$ SMB is the maximum SMB perturbation with respect to the unperturbed scenario, $\Delta L$ is the change in modeled glacier length, $\Delta x_{g l}$ is change in the grounding line position along the centerline, and $\Delta H_{g l}, \Delta U_{g l}$, and $F_{g l}$ are the glacier thickness, speed, and mass discharge at the grounding line, respectively. . . . . . . . 
4.3 Results for the freshwater in crevasses sensitivity tests at the final model year 2100, where $\Delta d_{f w}$ is the maximum freshwater depth perturbation with respect to the unperturbed scenario, $\Delta L$ is the change in modeled glacier length, $\Delta x_{g l}$ is change in the grounding line position along the centerline, and $\Delta H_{g l}, \Delta U_{g l}$, and $F_{g l}$ are the glacier thickness, speed, and mass discharge at the grounding line, respectively. . . . . . 


\section{LIST OF ABBREVIATIONS}

AP Antarctic Peninsula

OIB Operation IceBridge

NASA National Aeronautical and Space Administration

NSIDC National Snow and Ice Data Center

RACMO2.3 Regional Atmospheric Climate Model, version 2.3

RMSE root mean square error

SMB surface mass balance

SMR submarine melting rate 


\title{
LIST OF SYMBOLS
}

\author{
$A \quad$ rate factor \\ $B$ surface mass balance \\ E enhancement factor \\ $F_{g l} \quad$ ice mass flux across the grounding line \\ $H \quad$ ice thickness \\ $N \quad$ effective pressure \\ $Q \quad$ activation energy for creep \\ $R \quad$ universal gas constant \\ $R_{x x} \quad$ along-flow resistive stress \\ T temperature \\ U longitudinal Eulerian ice speed \\ W glacier width \\ $\beta \quad$ basal roughness factor \\ $\eta \quad$ effective viscosity of ice
}




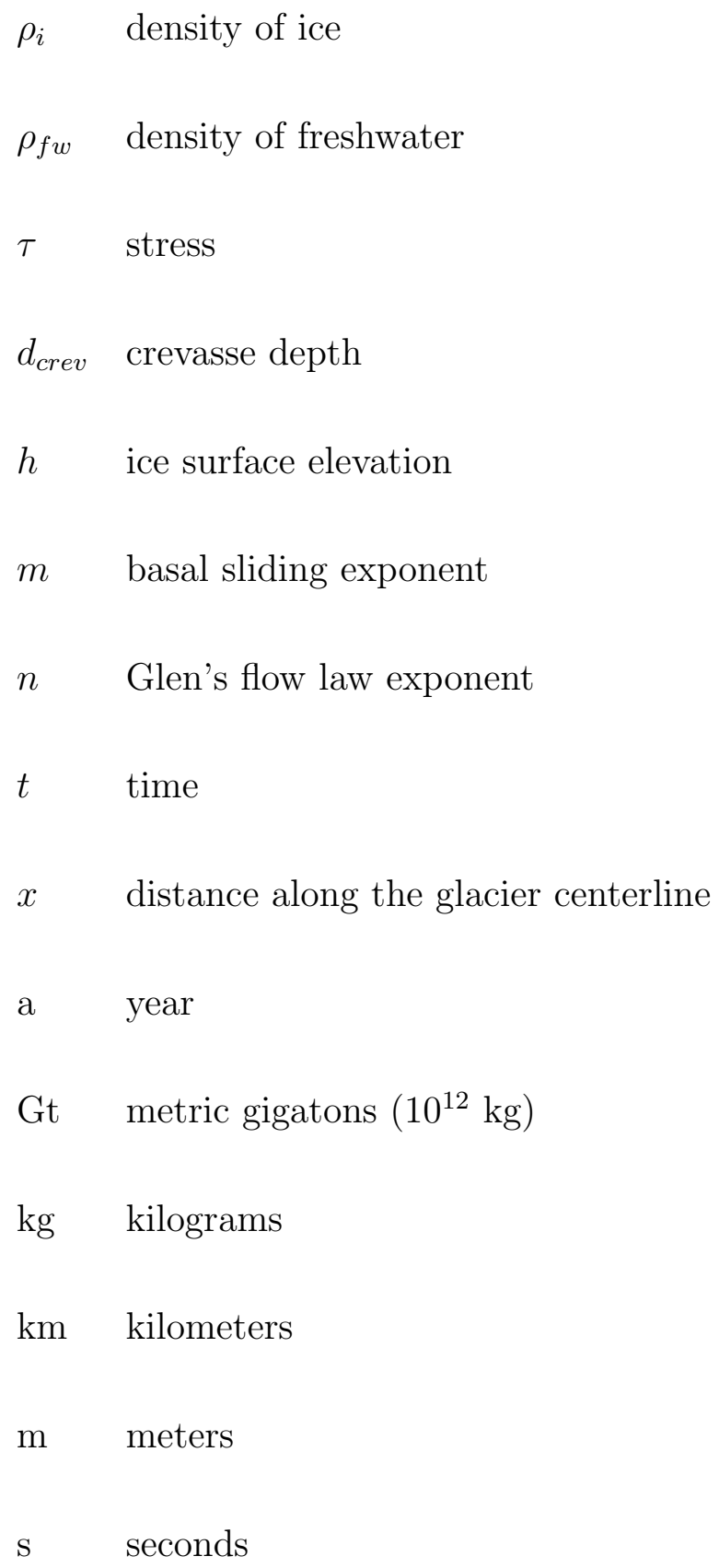




\section{CHAPTER 1: INTRODUCTION}

The collapse of the Larsen A and B ice shelves on the eastern Antarctic Peninsula (AP) in 1995 and 2002, respectively, removed substantial buttressing force from their former tributary glaciers, triggering glacier retreat, thinning, and accelerated mass loss (Rignot et al., 2004; Shepherd et al., 2018; Shuman et al., 2011). Possibly the most dramatic changes in dynamics have occurred at Crane Glacier, which increased its velocity twofold by early 2003 and threefold by late 2003 and has continued to flow at accelerated speeds, (Rignot et al., 2004; Berthier et al., 2012; Dryak \& Enderlin, 2020), driving an advance of $\sim 8.7 \mathrm{~km}$ in the past 12 years despite moderate deceleration (Dryak \& Enderlin, 2020). Former Larsen A tributaries such as Drygalski and Edgeworth Glaciers have also re-advanced and maintained increased speeds since the 1995 ice shelf collapse (Dryak \& Enderlin, 2020), but have changed minimally in length since 2014 (Fig. 1.1). In contrast, Fleming Glacier, which fed the Wordie Ice Shelf on the southwestern AP, remained relatively stable for $\sim 20$ years following the disintegration of the ice shelf in the 1960s-1990s before rapid thinning and accelerating in response to anomalous climate forcing (Friedl et al., 2018; Walker \& Gardner, 2017). These contrasting post-ice shelf collapse observations underline the complex interactions between long-term glacier geometric adjustment and ongoing climate forcing. 

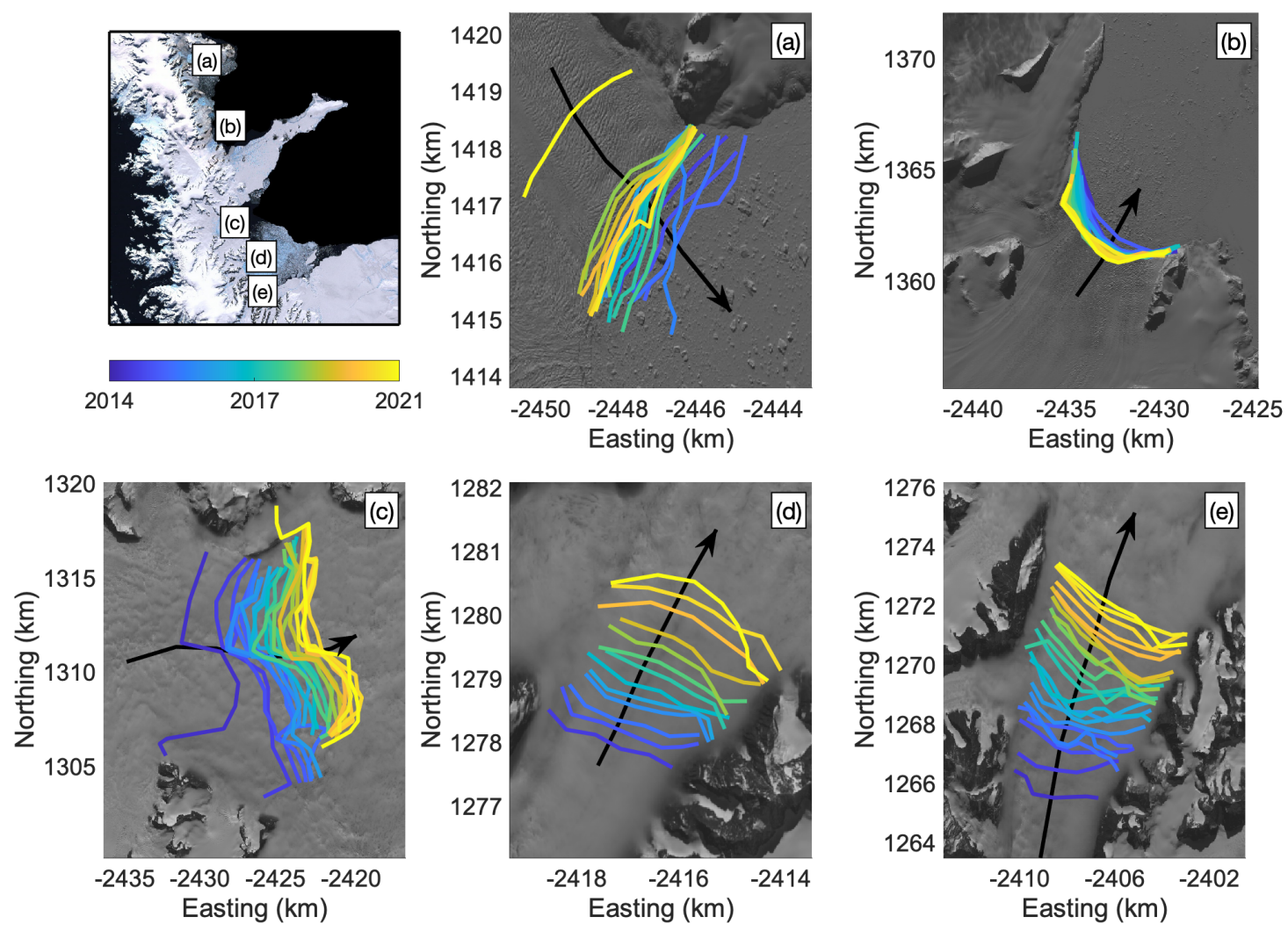

Figure 1.1: Map view of 2014-2021 terminus time series for former Larsen A ice shelf tributaries: (a) Edgeworth and (b) Drygalski Glaciers, and former Larsen B ice shelf tributaries: (c) Hektoria and Green, (d) Jorum, and (e) Crane Glaciers, colored by year. Black arrows indicate flow direction. Terminus positions are delineated using the Google Earth Engine Digitisation Tool (GEEDiT) and Margin change Quantification Tool (MaQiT) (Lea, 2018). Background images are from the panchromatic band of Landsat 8 imagery captured 10 January and 15 October 2020. The regional map (upper left) is the Landsat Image Mosaic of Antarctica with respective glacier locations marked. 
The relative importance of atmospheric and oceanic forcing on glacier dynamics varies around Antarctica. Along the AP, atmospheric warming has enhanced surface melting, leading to the collapse of several ice shelves via extensive surface melt waterdriven hydrofracture (van den Broeke, 2005; Borstad et al., 2012; Doake \& Vaughan, 1991). Oceanic warming may have preconditioned these ice shelves for catastrophic collapse (McGrath et al., 2012) and has driven the thinning and grounding line retreat of several outlet glaciers fringing the Antarctic ice sheets, including Pine Island (Christianson et al., 2016; Jenkins et al., 2010) and Thwaites Glaciers (Milillo et al., 2019; Seroussi et al., 2017; Joughin et al., 2014) in West Antarctica, and Totten Glacier in East Antarctica (Roberts et al., 2018; Rintoul et al., 2016). At decadal time scales, the magnitude of western AP glacier acceleration and retreat in response to dynamic frontal thinning (Pritchard \& Vaughan, 2007) has been correlated with regional ocean temperatures (Cook et al., 2016). Ocean forcing as an important control on glacier dynamics is further supported by the correlation between glacier frontal ablation rates (i.e., flow speed - terminus retreat rate) and iceberg melt rates, which are a proxy for local ocean conditions, across both sides of the AP (Dryak \& Enderlin, 2020). Over much shorter time scales, atmospheric forcing has been shown to strongly control dynamics: Tuckett et al. (2019) found that periods of glacier acceleration on the AP are coincident with visible melt water pooling caused by intense surface melting during austral summer foehn events.

Differences in ice shelf and glacier sensitivity to atmospheric and oceanic forcing can in part be explained by differences in geometry (Enderlin et al., 2013a; Felikson et al., 2017, 2021; Catania et al., 2018). The sparseness of environmental variables and correlations in their variability (e.g. seasonal ocean temperature and sea ice change) 


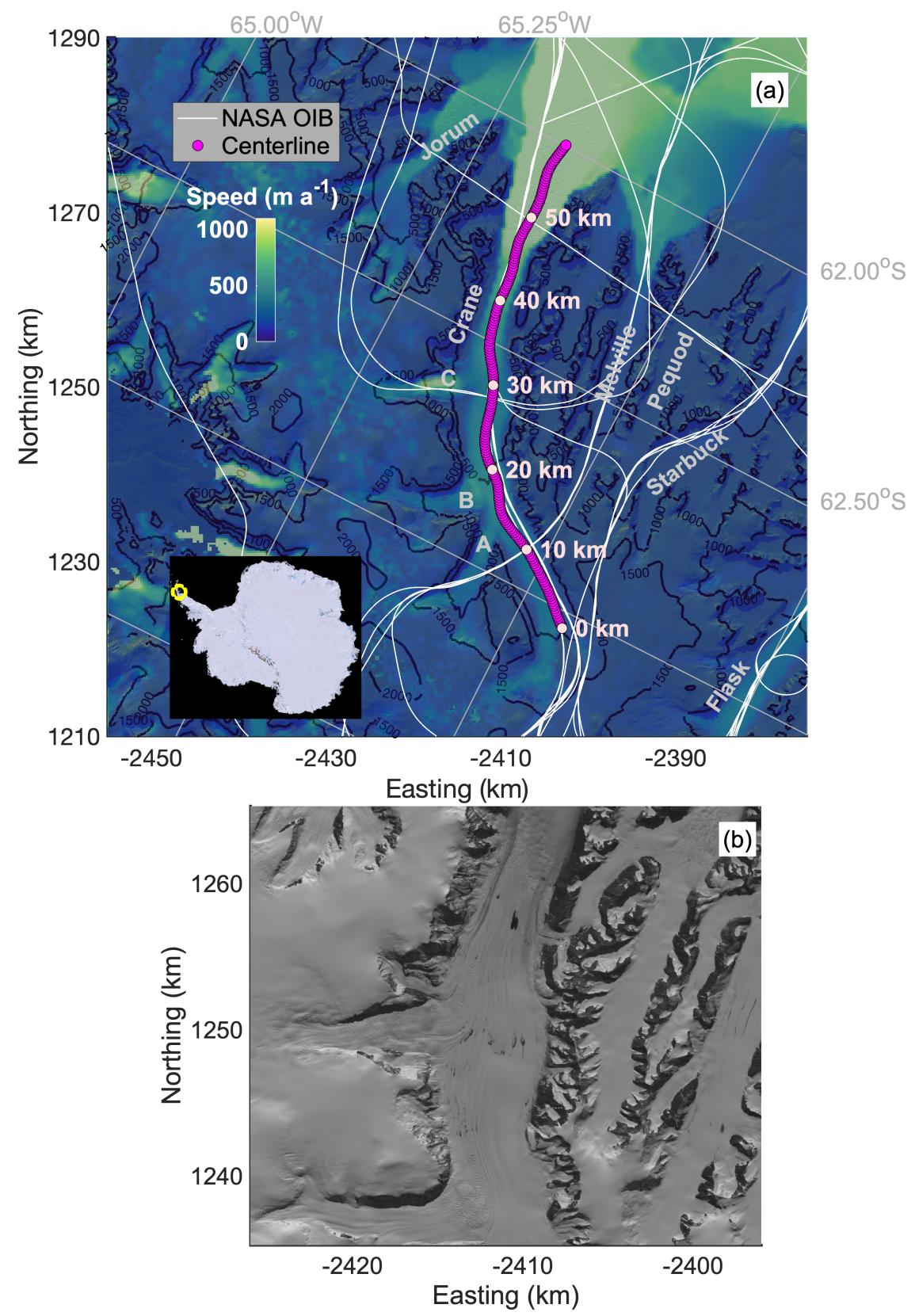

Figure 1.2: (a) Map of Crane Glacier, eastern Antarctic Peninsula. Labeled are the manually delineated glacier centerline where conditions are modeled with $10 \mathrm{~km}$ increments marked, NASA Operation IceBridge (OIB) flight paths, and surface speeds from 2017 NASA ITS_LIVE. Elevation contours are from the Reference Elevation Model of Antarctica in meters above sea level (Howat et al., 2019). Background image is the panchromatic band of Landsat 8 imagery captured 10 January 2020. Inset plot is the Landsat Image Mosaic of Antarctica with the study region circled (yellow). Adjacent glaciers and tributaries A, B, and C are labeled. (b) Near infrared band of the same Landsat image slightly zoomed in to lower elevations with visible melt water in pools and crevasses on the Crane Glacier surface. 
hinder observational analyses that aim to better understand controls on Antarctic glacier dynamics (Dryak \& Enderlin, 2020). Although modeling efforts have led to considerable advances in our understanding of several of the Antarctic ice sheets' largest glaciers (Seroussi et al., 2017; Favier et al., 2014; Gwyther et al., 2018), the glacier geometry and coastal bathymetry observations required by models are limited along the Antarctic Peninsula. Here, I investigate the primary controls on recent dynamic changes at Crane Glacier following the collapse of the Larsen B ice shelf in 2002. Specifically, I use a numerical ice flow model developed by Enderlin et al. (2013b) in combination with state-of-the-art surface mass balance (SMB) estimates, glacier flow speed and geometry observations, including radar and sonar observations of the glacier bed and ocean bathymetry, satellite-derived terminus positions, and iceberg-derived observations of recent ocean conditions adjacent to the Crane terminus (Dryak \& Enderlin, 2020) to constrain the recent dynamic history of the glacier. In addition, I use the SMB, submarine melt, and hydrofracture-induced calving model parameters to explore the glacier sensitivity to projections of $1^{\circ} \mathrm{C}$ atmospheric and ocean warming throughout the 21st century. Crane presents an ideal study location to model post-shelf collapse glacier dynamics due to the relative abundance of observational data. Additionally, the recent re-advance of Crane and other Larsen B tributaries (Fig. 1.1) contrasts both with the widespread retreat of glaciers along the western side of the Antarctic Peninsula and in West Antarctica as well as expected patterns based on recent atmospheric and oceanic forcing, which may suggest that their long-term dynamic mass loss is largely independent of climate. The limited understanding of regional glacier stability following ice shelf collapse presents uncertainties for projections of sea level rise contribution on the AP. 


\section{CHAPTER 2:}

\section{BACKGROUND}

\subsection{Ice dynamics}

Changes to a marine-terminating glacier's dynamic state, caused by processes such as iceberg calving, ice shelf collapse, or sea ice thinning, can lead to significant changes in glacier mass balance and subsequently, sea level rise (Liang et al., 2019). Increased surface mass balance (i.e., net accumulation and ablation summed over the glacier surface), for example, due to increased snowfall or decreased surface melt can lead to changes in annual mass loss (Pȩtlicki et al., 2017). Marine-terminating glaciers differ from land-terminating glaciers because their mass is controlled by SMB as well as frontal ablation at the ocean boundary through calving and submarine melting (Fig. 2.1). Their sensitivity to both atmospheric and oceanic forcing makes them generally more unstable than their land-terminating counterparts, however, their sensitivity to climate forcing varies tremendously with glacier geometry (Brinkerhoff et al., 2017; Enderlin et al., 2013a; Catania et al., 2018). Marine-terminating glaciers that maintain contact with the underlying terrain as they flow into the ocean (i.e., tidewater glaciers) often occupy over-deepened troughs that are carved by glacier erosion of the underlying bed. These glaciers are particularly susceptible to rapid changes in dynamics that are largely controlled by glacier geometry (Nick et al., 2007a; Amundson, 


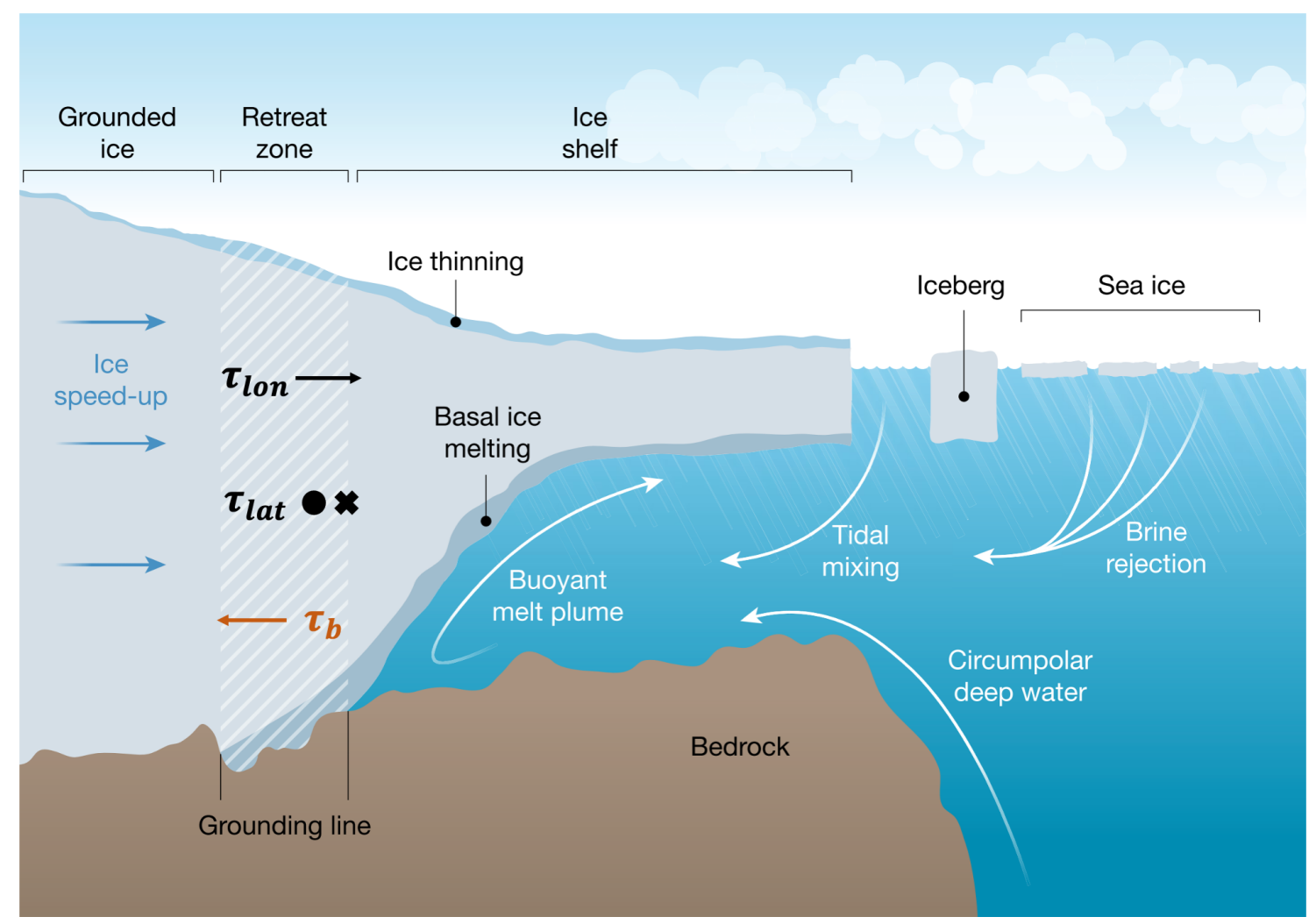

Figure 2.1: Modified from Shepherd et al. (2018). Diagram demonstrating glacier dynamics including ice shelf buttressing, external forcings, and stresses within the ice represented in Equation 2.2, where $\tau_{l o n}$ is the longitudinal stress, $\tau_{\text {lat }}$ is the lateral resistance, and $\tau_{b}$ is the basal resistance.

2016), as described below.

The asymmetrical cycle of internal dynamics-driven gradual long-term advance and rapid retreat of tidewater glaciers is referred to as the tidewater glacier cycle (Fig. 2.2). The tidewater glacier cycle consists of four main stages: (1) the advancing stage, in which the glacier thickens as it excavates sediment from the bed, creating a marine sediment shoal as it advances into the fjord, (2) the extended phase, in which the glacier ceases to advance and reaches near equilibrium due to balanced accumulation and ablation, (3) the retreat phase, in which the glacier can no longer 
maintain its thickness at the sediment shoal, triggering retreat into deeper water, and (4) the retracted phase, in which the glacier terminus stabilizes in shallow water (Brinkerhoff et al., 2017). During the retreat phase, thinning is greatest near the terminus but propagates inland as a kinematic wave, causing the glacier to steepen and driving stress to increase, which leads to long-term enhanced flow (Howat et al., 2008; Nick et al., 2009; Felikson et al., 2017). This cycle is largely independent of climate, although climate forcing influences the timing and frequency of retreat (Brinkerhoff et al., 2017).

Although the tidewater glacier cycle describes the asymmetric pattern of retreat and advance observed for marine-terminating glaciers that are grounded across overdeepened beds, glaciers with floating termini may also undergo similar cycles of rapid retreat and long-term re-advance. Ice shelf retreat reduces ice flow resistance (Fig. 2.1), which causes flow acceleration that stretches and thins its tributary glaciers. The impacts of shelf retreat on glacier dynamics are evident in the Larsen B embayment: glaciers that remain buttressed by the Larsen B ice shelf remnant, such as Flask and Leppard Glaciers, have maintained fairly steady speeds whereas tributary glaciers that fed the former ice shelf (Crane, Hektoria, Green, and Jorum Glaciers) retreated and accelerated immediately following shelf collapse (Rignot et al., 2004). The moderate deceleration of Larsen B former tributaries in recent years (Fig. 1.1) suggests that these glaciers may be reaching a more stable geometry $\sim 20$ years after shelf collapse. Glacier stabilization may be facilitated by the growth of floating ice tongues, as inferred by the presence of tabular icebergs sourced from Crane Glacier (Dryak \& Enderlin, 2020), which should buttress ice flow (Joughin et al., 2004; Vieli \& Nick, 2011). Thus, it is possible that glaciers with floating termini can undergo 


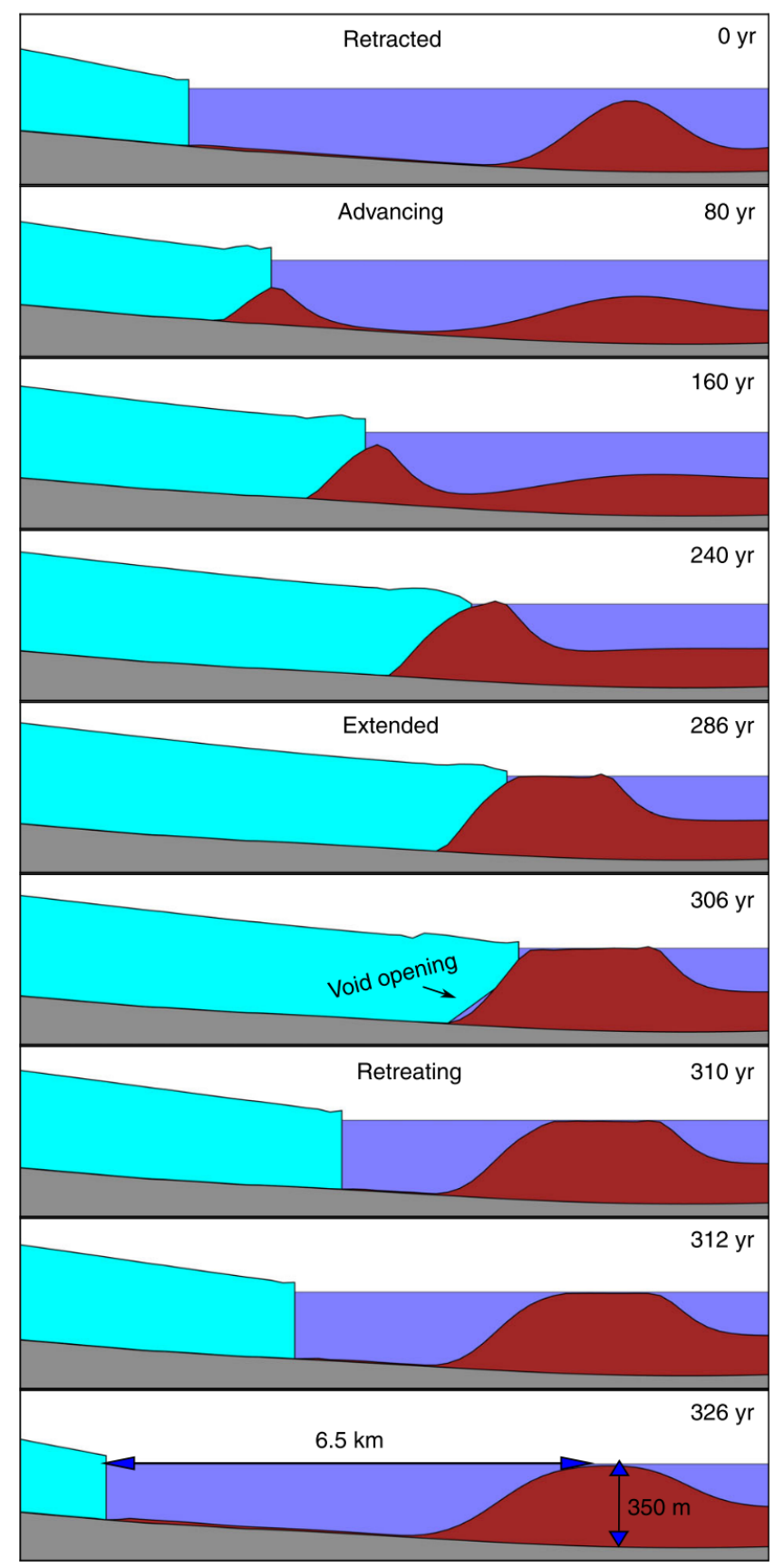

Figure 2.2: Modeled glacier geometry through a tidewater glacier cycle from Brinkerhoff et al. (2017). The panels are not uniformly distributed in time due to the asymmetric time scales of advance and retreat. In phase one, the glacier is retracted, then advances until $t=286$ years. At $t=306$ years, fluvial erosion thins the shoal's upstream end causing the glacier to come afloat. The beginning of this process is evident in the small void developing at the upstream end of the shoal. Over the next 20 years, the glacier retreats towards its initial state. 
asynchronous cycles of rapid retreat and gradual re-advance similar to the tidewater glacier cycle, but that are largely controlled by floating ice geometry (Fig. 2.2).

\subsection{Antarctic Peninsula Environmental Change}

Surface air temperatures warmed more along the AP in the late twentieth century than any other terrestrial environment in the Southern Hemisphere; what's more, regional air temperatures are projected to continue to increase by more than the global average in coming decades (Siegert et al., 2019). Ice melting in Antarctica is expected to double by 2050 with the highest rates of melt water production expected on the AP, where the sensitivity of glacier SMB to air temperature warming is far above global average (Hock et al., 2009). For every $1^{\circ} \mathrm{C}$ of near-surface air temperature increase since 1970, surface melt on the Larsen B ice shelf increased by about $83 \mathrm{~mm}$ water equivalent per year before its collapse in 2002 (Trusel et al., 2015). Atmospheric warming can also impact ice loss through its influence on ocean conditions. For example, substantial increases in atmospheric temperatures over the AP have been linked to nearby ocean warming and intensification of the circumpolar westerlies (Mayewski et al., 2009). Changes in atmospheric conditions can also alter the circulation of subsurface warm water on continental shelves on a wide range of spatial scales (Dutrieux et al., 2014; Paolo et al., 2018).

The upper kilometer of the Southern Ocean has warmed considerably in the past fifty years (Mayewski et al., 2009; Auger et al., 2020). Under the global $1.5^{\circ} \mathrm{C}$ air temperature warming scenario, the relatively warm and salty subsurface circumpolar deep water that is responsible for the highest rates of ice shelf submarine melting is predicted to become warmer and shallower, leading to enhanced ice shelf thinning

(Rignot et al., 2019; Siegert et al., 2019), and ultimately increased loss of ice and 
sea-level rise (Siegert et al., 2019; Shepherd et al., 2018; Adusumilli et al., 2018). The fjords of the eastern AP are fed by the relatively dense, cold Weddell Sea water, which is formed by intense interactions between the air, ice, and sea water (Mayewski et al., 2009). Although the upper depths of the Weddell Sea water have shown contrasting signals of warming and increased salinity, and cooling and freshening in recent decades (Schmidtko et al., 2014; Fahrbach et al., 2004), warming has been observed for depths below $700 \mathrm{~m}$ in the previous three decades (Strass et al., 2020). The recent widespread warming of the lower depths of the Weddell Sea has been attributed in part to interactions with the Antarctic Circumpolar Current. It is uncertain whether the current rate of heat transfer from the Weddell Sea to the deep ocean water will continue in coming decades (Strass et al., 2020).

\subsection{Flowline Model}

Width- and depth-integrated, or one-dimensional, numerical ice flow models (i.e., flowline models) are computationally efficient and can be used to model fast-flowing glaciers with relatively simple geometries and flow regimes (Benn et al., 2007). Flowline models have been used to model the behavior of glaciers in a wide variety of geographic settings including Greenland (Nick et al., 2009, 2012; Vieli \& Nick, 2011), Alaska (Nick et al., 2007a; Colgan et al., 2012), Svalbard (Vieli et al., 2001, 2002), Iceland (Nick et al., 2007b), and Antarctica (Jamieson et al., 2012). The flowline model used here was previously used to assess glacier sensitivity to climate change for a range of geometries and viscosities (Enderlin et al., 2013a,b).

The governing equations for the flowline model are shown in Equations 2.1-2.3 below. The linearization and discretization procedures required to solve the equations using finite difference methods are described in detail in Enderlin et al. (2013a). The 
temporal change in glacier thickness can be determined using conservation of mass:

$$
\frac{\partial H}{\partial t}=-\frac{1}{W} \frac{\partial(U H W)}{\partial x}+B
$$

where $H$ is the thickness [m], $t$ is the time $[\mathrm{s}], W$ is the width [m], $x$ is the distance along the centerline $[\mathrm{m}], U$ is the speed in the direction of flow (the positive $x$ direction) $\left[\mathrm{m} \mathrm{s}^{-1}\right]$, and $B$ is the surface mass balance $\left[\mathrm{m} \mathrm{s}^{-1}\right]$. In Eqn. 2.1, changes in thickness over time at a given point are balanced by the advection of ice from higher elevations and the net surface accumulation and ablation (SMB). Flow is dictated by conservation of momentum, such that the governing force balance equation is:

$$
2 \frac{\partial}{\partial x}\left(H v \frac{\partial U}{\partial x}\right)-\beta N U^{\frac{1}{m}}-\frac{H}{W}\left(\frac{5 U}{2 E A W}\right)^{\frac{1}{n}}=\rho_{i} g H \frac{\partial h}{\partial x}
$$

where $\beta$ is the basal roughness factor $\left[\mathrm{s}^{-\frac{1}{m}}\right], N$ is the effective pressure $[\mathrm{Pa}], m$ is the basal sliding exponent [unitless], $A$ is the rate factor $\left[\mathrm{Pa}^{-n} \mathrm{~s}^{-1}\right], E$ is the enhancement factor [unitless], $\rho_{i}$ is the density of ice $\left[917 \mathrm{~kg} \mathrm{~m}^{-3}\right], h$ is the surface elevation [m], and $v$ is the averaged effective ice viscosity [Pa s]. The right-hand side of Equation 2.2 represents the gravitational driving stress, which is balanced on the left-hand side by longitudinal stress gradients (1st term), basal resistance (2nd term), and lateral resistance (3rd term).

Ice is a non-linear viscous fluid, and the rate and enhancement factors, $A$ and $E$, determine the rate at which the ice deforms under a given stress. The rate factor $A\left[\mathrm{~Pa}^{-n} \mathrm{~s}^{-1}\right]$, which is controlled by ice temperature, water content, and grain size (Cuffey \& Paterson, 2010), is related to the shear strain $\epsilon$ [unitless] by Glen's Law 


\section{Table 2.1: Model Constants}

\begin{tabular}{|c|c|c|}
\hline Parameter & Value & Notes \\
\hline $\mathrm{E}$ & 1 & enhancement factor \\
$\rho_{i}$ & $917 \mathrm{~kg} \mathrm{~m}^{-3}$ & density of ice \\
$\rho_{f w}$ & $1000 \mathrm{~kg} \mathrm{~m}^{-3}$ & density of freshwater \\
$\mathrm{g}$ & $9.81 \mathrm{~m} \mathrm{~s}^{-2}$ & gravitational acceleration \\
$\mathrm{n}$ & 3 & Glen's flow law exponent \\
$\mathrm{m}$ & 3 & basal sliding exponent \\
$\Delta \mathrm{t}$ & $0.01 \mathrm{~s}$ & model time-step \\
$\Delta \mathrm{x}$ & $200 \mathrm{~m}$ & spatial grid spacing \\
\hline
\end{tabular}

(Glen, 1955):

$$
\dot{\epsilon}=A \sigma^{n}
$$

where $\sigma$ is the dominant shear stress $[\mathrm{Pa}]$. The enhancement factor $E$ is a nondimensional scalar used to account for additional ice deformation not accounted for by $A$, such as the development of anisotropic fabric or impurities in the ice (Enderlin et al., 2013a). I adopt widely accepted values for constants $E, m, n, \rho_{i}$, and $g$ (Table 2.1). Satellite-derived observations of glacier surface elevation and speed, bed elevation, and width and modeled SMB and air temperature are used to tune the remaining parameters to best reproduce observed conditions in the model, as described below. 


\section{CHAPTER 3:}

\section{METHODS}

\subsection{Glacier Geometry Observations}

To create the time series of observations along the glacier centerline required by the width- and depth-integrated flowline model, I manually delineate the Crane Glacier center flowline (centerline) at $200 \mathrm{~m}$ increments using visible surface flowlines in the panchromatic band of Landsat 8 imagery captured 15 October 2020, shown in Figure 1.2. Centerline observations of surface elevation are from both NASA Operation IceBridge (OIB) level 2 products (Paden et al., 2010) available for 2009-2011 and 20162018 at $22 \mathrm{~m}$ resolution with a nominal error of $10 \mathrm{~m}$ (Gogineni et al., 2001) through the National Snow and Ice Data Center (NSIDC) data portal (https://nsidc.org/ icebridge/portal/map), and WorldView-derived digital elevation models produced by the Polar Geospatial Center available for 2011-2017 at 2 m resolution (Table 3.1) with an accuracy of $\sim 5 \mathrm{~m}$ (Shean et al., 2016; Noh \& Howat, 2015). Surface speeds are from NASA ITS_LIVE for 2013-2017 at $240 \mathrm{~m}$ resolution with a mean error of $\sim 38 \mathrm{~m} \mathrm{a}^{-1}$ (Gardner et al., 2020), available through the NSIDC data portal (https://nsidc.org/icebridge/portal/map), and TerraSAR-X from the German Aerospace Center (DLR) and EADS Atrium, which extends to as early as 1995 at $50 \mathrm{~m}$ resolution. Manually-delineated glacier terminus positions from all cloud-free 
Landsat images since 2002 from Dryak \& Enderlin (2020) are used to extrapolate terminus positions along the centerline since 2009 (Fig. 3.2c).

Because the flowline model is width-integrated, the model requires flow-following profiles of glacier width, width-averaged speed, and width-averaged thickness. To construct these profiles, I manually delineate the glacier extent using the 15 October 2020 Landsat 8 panchromatic image. Line segments that extend perpendicular to each centerline point are automatically clipped using the glacier extent polygon in order to construct a glacier width profile (Fig. 3.1). The glacier surface speed interpolated at $200 \mathrm{~m}$ intervals along each cross-glacier line segment is used to construct widthaveraged speed profiles(Fig 3.2b). Annual width-averaged glacier thickness estimates are computed by adjusting the sonar- and radar-derived bed elevation profile, as described below.

The NASA OIB level 2 products, which provide surface and bed elevation estimates, contain sparse bed elevation observations for all missions at Crane Glacier. The model initialization requires a complete glacier bed elevation profile. Therefore, I construct the glacier centerline bed elevation profile from two adjacent swaths of the 2018 NASA OIB level 1B data product (Paden et al., 2014) passing over Crane (Fig. 1.2) using code adapted from John Paden (CReSIS, 2020) at the University of Kansas by Tate Meehan at Boise State University. Gain control is automatically applied to the NASA OIB radar echograms, which are then plotted as distance along the flight line with respect to the geoid (i.e., orthometric elevations). The user can then adjust the image contrast so that visual inspection of the plot reveals a distinct echo from the surface and ice-bedrock boundary. Once the returns have been manually selected, a smooth elevation profile is automatically constructed using a piecewise cubic hermite 


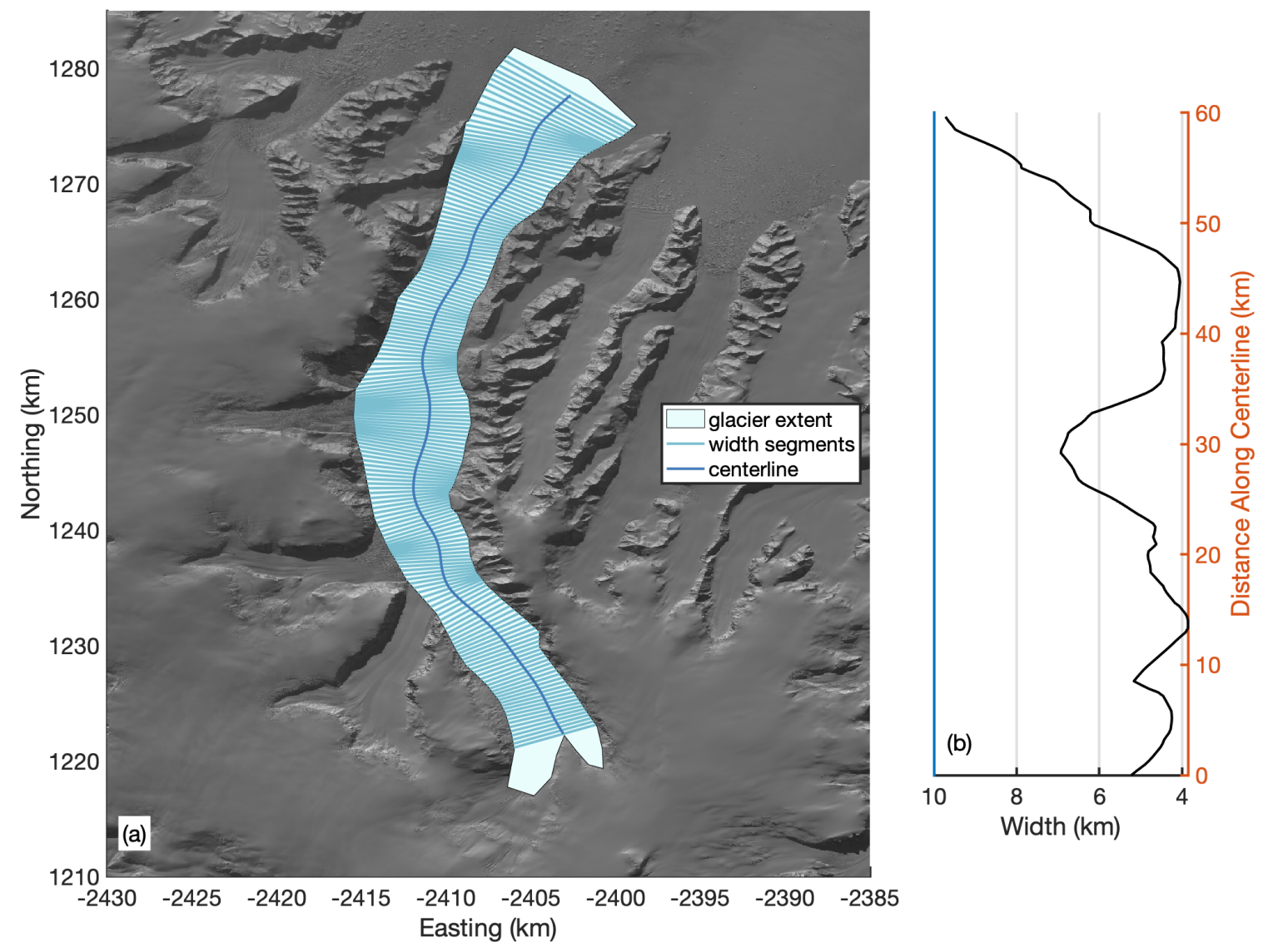

Figure 3.1: (a) Map view of the glacier extent polygon used to clip line segments perpendicular to the glacier centerline, creating width segments. The background image is a Landsat 8 panchromatic image from 13 October 2019. (b) The glacier width profile. 
interpolating polynomial function. The bed elevation near the ice divide provided by the OIB level 2 data product and sonar-derived fjord bathymetry obtained near the terminus in 2006 (Rebesco et al., 2014) are used to constrain the start and end points of the manually-delineated bed elevation profile.

To estimate the width-averaged thickness, I first calculate the estimated thickness along the centerline using the earliest available surface elevation profile (2007) and the centerline bed elevation profile. Sonar data from Crane fjord near the terminus (Rebesco et al., 2014) show that the bed shape is nearly parabolic. Therefore, at each centerline point, I compute the parabolic cross-sectional area assuming that the maximum thickness is along the centerline, the thickness goes to zero at the glacier margins, and the surface elevations are uniform across the glacier width. The resulting bed elevation profile leads to a width-averaged thickness that is $\sim 66 \%$ of the centerline thickness, shown in Fig. 3.2a.

\subsection{Boundary Fluxes}

Glacier mass balance is by definition the difference between input and output mass fluxes summed over the entire glacier (Cuffey \& Paterson, 2010). Inputs include ice flux from the glacier interior and existing tributaries and snow accumulation. Outputs include surface melt water runoff, submarine melting, and iceberg calving. Influx from the model interior, iceberg calving, snow accumulation and surface melt water runoff (i.e., surface mass balance), submarine melting, and influx from tributaries are described in the following paragraphs.

The interior flux is calculated at the inward-most model grid cell using the speed, width, and thickness at the adjacent model grid cell. At the seaward boundary, the longitudinal stress is balanced by the difference between the hydrostatic pressure 

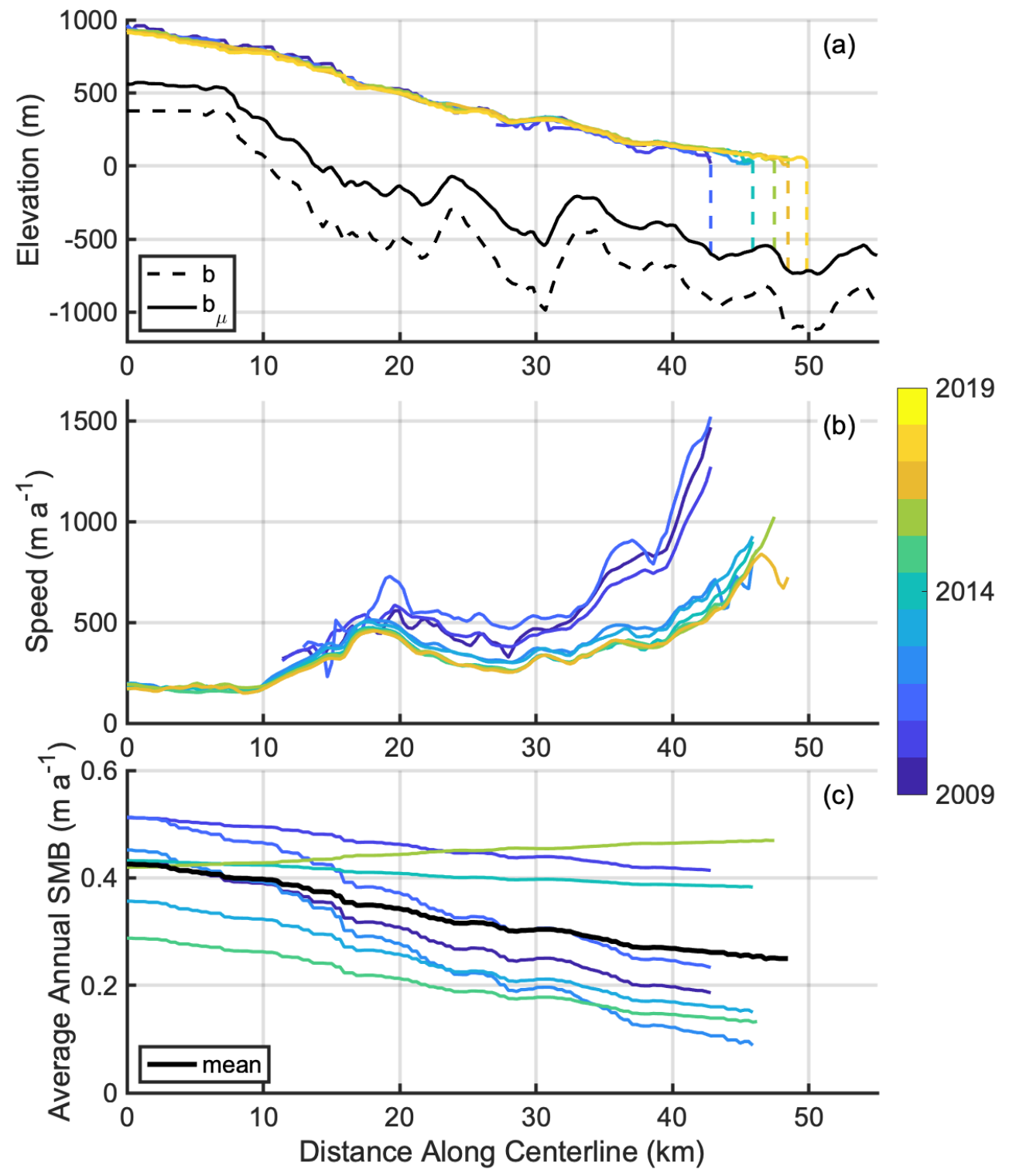

Figure 3.2: Time series of glacier centerline observations for (a) surface elevations, the radar- and sonar-derived bed elevation profile $b$ (dashed line), the width-averaged bed elevation profile $b_{\mu}$ (solid line), (b) widthaveraged surface speeds, and (c) modeled surface mass balance (SMB) statistically downscaled from RACMO2.3 using methods described by Noël et al. (2016), with the time-averaged SMB for 2009-2019 indicated by the black line. Colors of lines indicate the date of observation, shown in the color bar (right). Dashed vertical lines in panel (a) represent the estimated terminus positions from (Dryak \& Enderlin, 2020) corresponding to the surface elevation observation date. 
of the ice and seawater. Near marine-terminating termini, longitudinal stretching from ice flow acceleration (Fig. 3.2b) creates dense fields of extensional crevasses. Crevasse closure is driven by the weight of the ice overburden and opening is driven by extensional resistive stresses and by impounded surface melt water (where it exists). Surface crevasses will penetrate to the depth in the ice where the net stress is zero. The depth of crevasses, $d_{\text {crev }}$, is calculated as:

$$
d_{\text {crev }}=\frac{R_{x x}}{\rho_{i} g}+\frac{\rho_{f w}}{\rho_{i}} d_{f w}
$$

where $\rho_{f w}$ is the density of fresh water $\left[1000 \mathrm{~kg} \mathrm{~m}^{3}\right], d_{f w}$ is the fresh water depth in crevasses [m] , and $R_{x x}$ is the along-flow resistive stress [Pa], defined as:

$$
R_{x x}=2\left(A^{-1} \frac{\partial U}{\partial x}\right)^{1 / n}
$$

in accordance with Glen's flow law (Nick et al., 2010; Enderlin et al., 2013b). The calving front is identified as the inland-most ungrounded grid cell in which the surface crevasse depth equals the surface elevation (i.e., the crevasse penetrates to sea level), assuming that the fracture of ice along pre-existing crevasses is a large-scale, firstorder control of iceberg calving (Benn et al., 2007; Nick et al., 2010; Enderlin et al., 2013a). The crevasse penetration depth calving parameterization does not model individual calving events, but has been shown to reproduce interannual patterns in terminus position with high fidelity with respect to other leading calving models for outlet glaciers in Greenland (Choi et al., 2018; Amaral et al., 2020). Additionally, the chosen parameterization allows for the consideration of crevasse hydrofracture, and melt water runoff-driven changes in hydrofracture over time, as a control on ter- 
minus position. The Larsen B ice shelf collapse has been attributed to hydrofracture (Scambos et al., 2000; McGrath et al., 2012; Robel \& Banwell, 2019). Additionally, impounded melt water is visible on the Crane Glacier surface in recent austral summer satellite images (Fig. 1.2b), suggesting that hydrofracture must be included in the calving parameterization.

There are no direct observations of SMB at Crane Glacier, requiring the use of modeled SMB estimates as a model input. Therefore, the $\sim 5.5 \mathrm{~km}$-resolution monthly SMB product from RACMO2.3 (Van Wessem et al., 2016; Lenaerts et al., 2018) is employed to create the centerline SMB profile. I statistically downscale the RACMO2.3 SMB product to the glacier surface along the centerline using methods described by Noël et al. (2016) in order to account for topographic effects that are not resolved at the coarser native resolution of the SMB product. For each centerline point, I interpolate the mean annual SMB and elevation for $\sim 6-8$ adjacent grid cells, compute a linear trendline of SMB vs. elevation, translate the trendline such that it intersects with the current grid cell, and then evaluate SMB at the observed Crane surface elevation from the translated trendline. I then convert the units from meters of annual water equivalent to annual ice thickness assuming uniform densities for ice and fresh water (Table 2.1). The time-averaged SMB for 2009-2019 is used to initialize the model in order to minimize the influence of random errors, estimated as $\sim 10 \%$ of the SMB, on the downscaled SMB estimates. The downscaled annual time series and time-averaged SMB along the centerline are shown in Figure 3.2d.

Submarine melting from the base of the floating ice tongue, when one exists, requires the modification of the SMB profile so that it accounts for all vertical mass fluxes. Previous observations have shown that for marine-terminating glaciers and ice 
shelves, submarine melt is highest near the glacier grounding line, driven by convective motion of freshwater ejected from the glacier base at the grounding line (Jenkins, 2011; Adusumilli et al., 2020). To simulate the along-flow decrease in melt rate and to maintain a smooth transition in vertical mass flux across the grounding line, submarine melt is prescribed as $0 \mathrm{~m} \mathrm{a}^{-1}$ at the grounding line, rapidly increasing to a maximum melt rate at the adjacent grid cell (200 m further along the centerline), and decreasing linearly by an additional $0.1 \%$ of the maximum melt rate for each additional $200 \mathrm{~m}$ distance from the grounding line. The non-perturbed maximum submarine melt rate of $\sim 5.3 \mathrm{~m} \mathrm{a}^{-1}$ is based on the maximum melt rate for icebergs adjacent to Crane's terminus for 2013-2017 (Dryak \& Enderlin, 2020). This submarine melt rate is slightly higher than the 1994-2016 area-averaged rate of $0.5 \pm 1.4 \mathrm{~m} \mathrm{a}^{-1}$ (Adusumilli et al., 2018) and is near the maximum 2010-2018 average basal melt rate of $\sim 5 \mathrm{~m} \mathrm{a}^{-1}$ computed for the Larsen C ice shelf (Adusumilli et al., 2020).

There are three tributaries that contribute mass to Crane Glacier. These tributaries, referred to as $\mathrm{A}, \mathrm{B}$, and $\mathrm{C}$, are located at $\sim 15,20$, and $30 \mathrm{~km}$ along the centerline, respectively (Fig. 1.2). To estimate the annual mass contributions from each of the Crane tributaries, I extract surface elevation and speed data across a flux gate which is manually drawn perpendicular to flow using Landsat 8 panchromatic imagery from 15 October 2020. Bed elevations are required to convert surface elevation observations to thicknesses. However, bed elevation observations are only available along OIB flow-following flight lines for tributary C (Fig. 1.2). I construct the crosssectional thickness for the tributary $\mathrm{C}$ flux gate using the thickness observations at the center of the flux gate and assuming a trapezoidal, parabolic, and rectangular bed geometries. The mean of these geometries is used to account for uncertainties in 
Table 3.1: Datasets employed for time series of glacier surface elevation, bed elevation, surface speed, modeled surface mass balance, and terminus positions with corresponding spatial resolution, temporal coverage, and mean reported error.

\begin{tabular}{|c|c|c|c|c|}
\hline Dataset & Output & $\begin{array}{c}\text { Spatial } \\
\text { Resolution }\end{array}$ & $\begin{array}{l}\text { Temporal } \\
\text { Coverage }\end{array}$ & $\begin{array}{c}\text { Mean } \\
\text { Reported } \\
\text { Error }\end{array}$ \\
\hline $\begin{array}{l}\text { WorldView- } \\
\text { derived } \\
\text { DEMs }\end{array}$ & $\begin{array}{l}\text { Surface } \\
\text { elevation }\end{array}$ & $2 \mathrm{~m}$ & $2011-2017$ & $5 \mathrm{~m}$ \\
\hline $\begin{array}{c}\text { NASA OIB } \\
\text { level } 2 \\
\text { (IRMCR3) }\end{array}$ & $\begin{array}{l}\text { Surface } \\
\text { elevation }\end{array}$ & $22 \mathrm{~m}$ & $\begin{array}{l}\text { 2009-2011, } \\
2016-2018\end{array}$ & $10 \mathrm{~m}$ \\
\hline $\begin{array}{c}\text { NASA OIB } \\
\text { level 1B } \\
\text { (IRMCR1B) }\end{array}$ & $\begin{array}{c}\text { Glacier bed } \\
\text { elevation }\end{array}$ & $22 \mathrm{~m}$ & $2016-2018$ & $\sim 10 \mathrm{~m}$ \\
\hline $\begin{array}{c}\text { NASA } \\
\text { ITS_LIVE }\end{array}$ & Surface speed & $240 \mathrm{~m}$ & $2013-2017$ & $\sim 38 \mathrm{~m} \mathrm{a}^{-1}$ \\
\hline TerraSAR-X & Surface speed & $50 \mathrm{~m}$ & $2007-2013$ & $18 \mathrm{~m} \mathrm{a}^{-1}$ \\
\hline RACMO2.3 & $\begin{array}{c}\text { Modeled } \\
\text { surface mass } \\
\text { balance }\end{array}$ & $\sim 5.5 \mathrm{~km}$ & $1950-2018$ & $\sim 10 \%$ \\
\hline $\begin{array}{l}\text { Landsat } \\
\text { imagery }\end{array}$ & $\begin{array}{l}\text { Terminus } \\
\text { positions }\end{array}$ & $15 \mathrm{~m}$ & $2002-2021$ & 1-2 pixels \\
\hline
\end{tabular}

cross-sectional area, which varies by a maximum of $34 \%$. Thickness cross sections for the tributary A and B flux gates are estimated using the width to centerline thickness ratio of tributary $\mathrm{C}$. The product of speed, thickness, and width for $200 \mathrm{~m}$-resolution bins spanning each flux gate is then summed to estimate volume flux. I divide these fluxes by the width of Crane's trunk at the tributary confluence, resulting in a mean annual width-averaged ice thickness input from each tributary to the Crane trunk. 


\subsection{Model Initialization}

To execute the flowline model, the basal and terminal boundary conditions must be parameterized using observational data. Although the governing force balance equation (Eqn 2.2) can be used to solve for the basal boundary condition when the ice is grounded, the equation can only be solved if the rate factor $A$ and the enhancement factor $E$ are independently parameterized. $A$ and $E$ control the depth-averaged effective viscosity [Pa s], defined as follows,

$$
v=(E A)^{-\frac{1}{n}}\left|\frac{\partial U}{\partial x}\right|^{\frac{1-n}{n}}
$$

I first estimate the rate factor $A$ as a function of air temperature using the Arrhenius relationship:

$$
A=3.5 \cdot 10^{-25} e^{-\frac{Q}{R T}}
$$

where $T$ is the air temperature $[\mathrm{K}], Q$ is the activation energy for creep $\left[\sim 60 \cdot 10^{3} \mathrm{~J}\right.$ $\left.\mathrm{mol}^{-1}\right]$, and $R$ is the universal gas constant $\left[8.314 \mathrm{~J} \mathrm{~mol}^{-1} \mathrm{~K}^{-1}\right.$ (Cuffey \& Paterson, 2010). For T, I use the mean annual RACMO2.3 air temperature for 1998-2018, adjusted for elevation assuming a dry adiabatic lapse rate of $9.8 \cdot 10^{-3}{ }^{\circ} \mathrm{C} \mathrm{m}^{-1}$. The temperature-based $A$ is then adjusted to account for strain heating of the ice as it advects towards the terminus (Enderlin et al., 2013a). To do this, first strain rates are calculated using width-averaged surface observations of speed along the centerline. Next, the time it takes for ice to advect between each centerline point (i.e., advection time) is computed from the speed observations. Finally, the strain accumulated between centerline points is calculated as the product of the strain rate and advection time, then integrated along flow to construct the average strain profile 


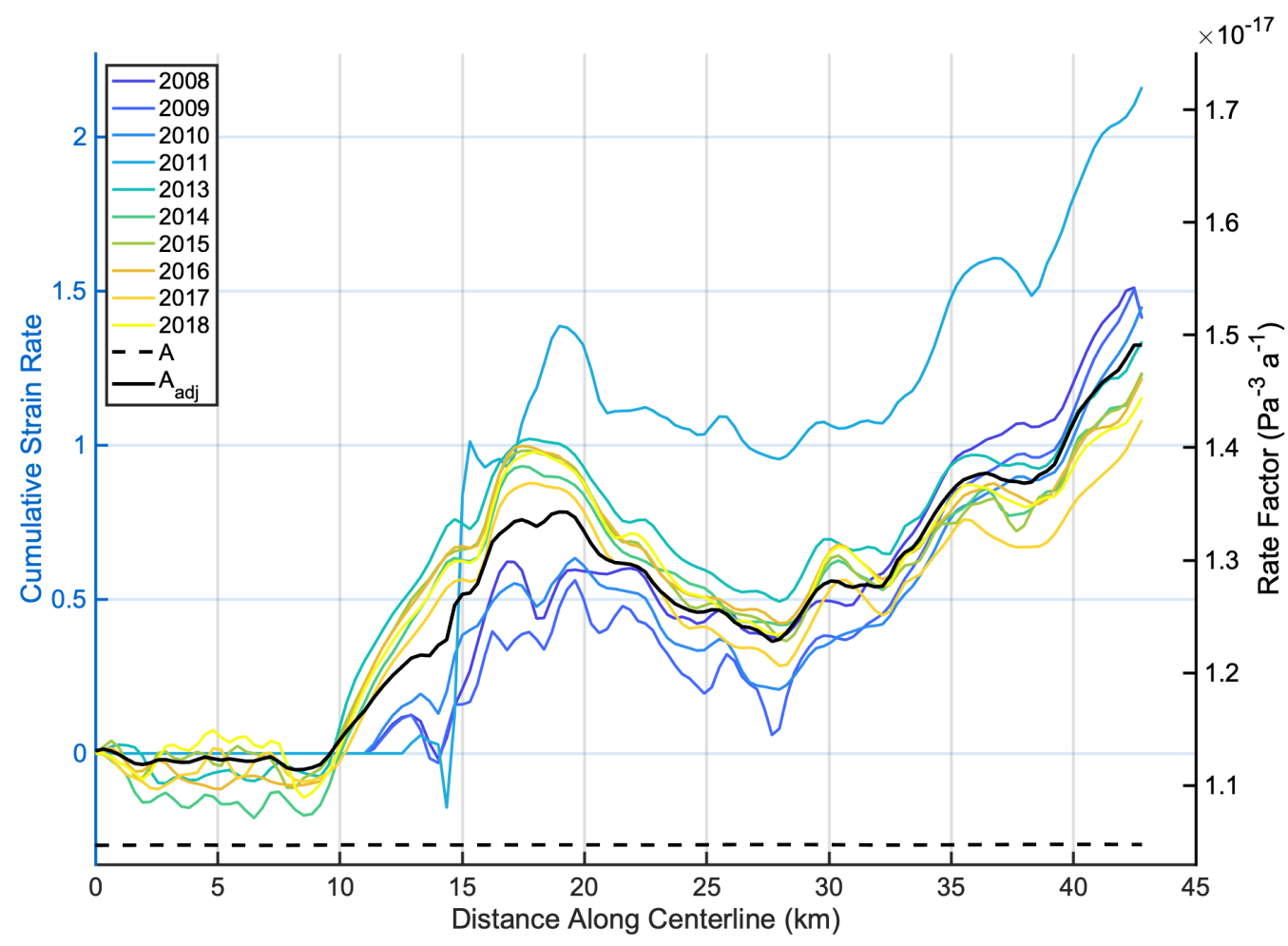

Figure 3.3: Average annual strain profiles estimated using centerline observations of speed for 2008-2018 (left $\mathrm{y}$-axis) and the temperature-dependent rate factor, $A$, adjusted using the average strain profile, $A_{a d j}$ (right $\mathbf{y}$-axis).

for years 2008-2018 (Fig. 3.3a). The average strain profile is then normalized from 1 to 2 to create a scalar multiplier analogous to the enhancement factor. The rate factor profile used in the model simulations is the product of the normalized strain profile and the temperature-dependent $A$, as shown in Figure 3.3.

Next, the basal roughness factor, $\beta$, that controls the basal boundary condition (Eqn. 2.2) is estimated by initializing the flowline model with 2009 observations and running the model until 2018. The modeled and observed speeds from 2018 are used 
to solve for $\beta$ using a gradient descent approach to minimize the cost function $J$ :

$$
J=\frac{\sum_{1}^{n}\left[\sqrt{U_{m o d}-U_{o b s}-U_{\sigma}}+\nabla^{2} K\right]}{n}
$$

where $n$ is the number of centerline points [unitless], $U_{m o d}$ is the modeled speed [m $\left.\mathrm{a}^{-1}\right], U_{o b s}$ is the width-averaged observed speed $\left[\mathrm{m} \mathrm{a}^{-1}\right], U_{\sigma}$ is the uncertainty in speed observations $\left[\sim 38 \mathrm{~m} \mathrm{a}^{-1}\right]$, and $K$ is a regularization term [unitless], defined as:

$$
K=\log (\beta)
$$

which penalizes changes in the gradient of the solution, modified from Larour et al. (2012); Morlighem et al. (2010); Kyrke-Smith et al. (2018). Based on a preliminary course grid search to test the model stability resulting from varying values for $\beta$, the lower and upper boundaries for the solution of $\beta$ at all points are defined as 0 and 10, respectively. The solution for $\beta$ is shown in Figure 3.4c.

Following the $\beta$ calculation, I further tune the model to minimize the misfit between modeled and observed calving front position after a 10 year simulation using the depth of freshwater impounded in crevasses, $d_{f w}$, implemented in the crevasse penetration depth calving parameterization (Eqn. 3.1). I solve for the optimal $d_{f w}$ of $\sim 6 \mathrm{~m}$ by first initializing the model using 2009 centerline observations (Fig. 3.2), then conduct a brute force coarse grid search ranging from 0 to $20 \mathrm{~m}$ to determine the value for $d_{f w}$ which minimizes the modeled calving front position misfit for 20102019. I then use this value as a starting point to fine tune $d_{f w}$ using a gradient descent function. At the grounding line, the 2018 modeled surface speed and elevation misfit are $28 \mathrm{~m} \mathrm{a}^{-1}$ and $-65 \mathrm{~m}$, respectively, relative to centerline observations (Fig. 3.4). 

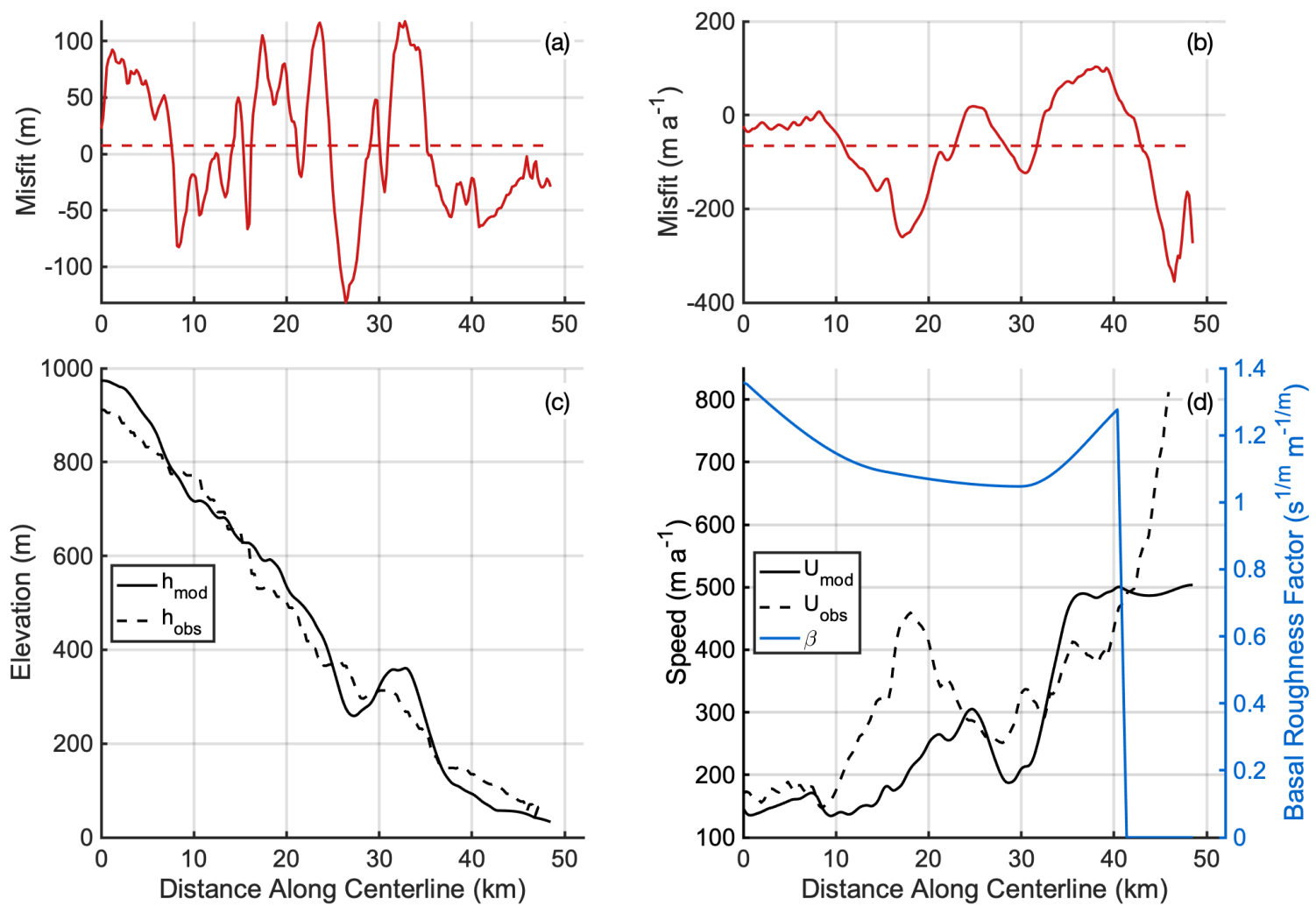

Figure 3.4: Model misfits calculated with respect to 2018 observed conditions resulting from the model run of 2009-2018 using all tuned parameters. (a) The surface elevation misfit and (b) the surface speed misfit. (c) $h_{m o d}$ and $h_{o b s}$ are the modeled and observed 2018 surface elevation along the profile and (d) $U_{m o d}$ and $U_{o b s}$ are the modeled and observed 2018 speed, respectively. The dashed lines in panels (a) and (b) represent the average 2018 misfit along the centerline. 


\subsection{Model Sensitivity Tests}

To model the sensitivity of Crane Glacier to changes in atmospheric and oceanic conditions, the 10 year hindcasting simulation described above is used to spin-up the model so that it reasonably reproduces 2009-2019 speed and terminus positions. The model is then used to simulate Crane Glacier's response to gradual linear warming of $1^{\circ} \mathrm{C}$ by 2100 of both ocean and air temperatures by proxy of the submarine melt rate and SMB parameters. The impact of atmospheric warming on terminus stability is also explored through perturbations in the depth of fresh water in crevasses, $d_{f w}$ (Eqn. 3.1). The 2100 grounding line and terminus positions as well as the grounding line speed, thickness, and discharge from each scenario are compared to the unperturbed model run in 2100 as described below.

For submarine melting, the ten maximum melt rate perturbations $(\Delta \mathrm{SMR})$ tested range from $0 \mathrm{~m} \mathrm{a}^{-1}$ to $+10 \mathrm{~m} \mathrm{a}^{-1}$ in increments of $+1 \mathrm{~m} \mathrm{a}^{-1}$, where positive values represent increased melting along the base of the floating ice tongue. These increased submarine melt rates are comparable to those found recently for ice shelves around the continent (Adusumilli et al., 2018, 2020). Although the upper depths of the Weddell Sea have slightly cooled and freshened in recent decades (Schmidtko et al., 2014), the Circumpolar Deep Water which lies a few hundred meters beneath the surface has warmed in recent years and is expected to become warmer and shallower in the coming years (Siegert et al., 2019). A $1{ }^{\circ} \mathrm{C}$ ocean temperature warming may be possible on the AP in future decades and will increase basal melt rates by up to 10 $\mathrm{m} \mathrm{a}^{-1}$ (Rignot \& Jacobs, 2002). For each ocean temperature warming simulation, a linear increase in the maximum submarine melt rate is applied from 2019 until 2100.

For SMB, the ten perturbations $(\triangle \mathrm{SMB})$ tested range from $0 \mathrm{~m} \mathrm{a}^{-1}$ to $-10 \mathrm{~m}$ 
$\mathrm{a}^{-1}$ in increments of $-1 \mathrm{~m} \mathrm{a}^{-1}$, where negative values indicate increased melting or decreased accumulation. For each air temperature warming scenario, the model is run through the 10 year hindcasting simulation then an incremental increase in the SMB gradient is applied by decreasing SMB as a function of elevation with respect to the initial values until reaching the maximum melt rate near sea level in 2100 . The annual surface melt water production at the Larsen $\mathrm{C}$ ice shelf, southeast of the Larsen B embayment, is expected to increase two- to threefold by 2100 under varying air temperature warming scenarios (Trusel et al., 2015). The statistically downscaled RACMO2.3 snowmelt product models 2019 mean annual snowmelt as 1$5 \mathrm{~m} \mathrm{a}^{-1}$ along the centerline, with values increasing spatially from the glacier interior to the terminus. The maximum surface melt scenario of $-10 \mathrm{~m} \mathrm{a}^{-1}$ therefore represents an approximate doubling of the current modeled snowmelt near sea level. The RACMO2.3 SMB product (Van Wessem et al., 2016) RACMO2.3 models zero melt water runoff for the eastern AP in recent years. However, this is contrary to what is expected at Crane based on previous estimates of non-negligible runoff for glaciers on the AP (Vaughan, 2006), the melt water in surface ponds and crevasses visible in recent satellite imagery captured in the austral summer (Fig. 1.2b), as well as the anomalously high melt rates for large icebergs adjacent to the Crane and Edgeworth Glacier termini, attributed to the emergence of subglacial melt water plumes (Dryak \& Enderlin, 2020). I assume that the absence of runoff reflects the $5.5 \mathrm{~km}$-resolution of RACMO2.3, such that the average surface elevations in the RACMO2.3 grid cells spanning the glacier are hundreds of meters greater than the glacier surface elevations. Based on these discrepancies, it is reasonable to assume that all snowmelt near sea level reported in the RACMO2.3 SMB product in recent years represents saturated 
firn such that there is no refreezing.

For $d_{f w}$, the ten perturbations tested range from $0 \mathrm{~m}$ to $10 \mathrm{~m}$ in increments of +1 $\mathrm{m}$ with respect to the optimal solution $(\sim 6 \mathrm{~m})$, where negative values represent decreased water depth and positive values represent increased water depth in crevasses. Contrary to the SMB perturbations, I assume here that all snowmelt is impounded in crevasses rather than lost as runoff. Previous work by Cook et al. (2012) demonstrated the substantial change in calving rate in response to changes in $d_{f w}$ on the scale of a few meters. Here, $d_{f w}$ is increased linearly at each time step until reaching the maximum change in 2100 for each perturbation. 


\section{CHAPTER 4: RESULTS}

The results for each of the sensitivity tests described above are shown in Figures 4.1-4.3 below. Changes in the terminus and grounding line position, as well as grounding line speed, thickness, and mass discharge, $F_{g l}$, are reported for model year 2100 in Tables 4.1-4.3. The $F_{g l}$ is calculated using the glacier grounding line thickness, speed, and width, assuming a uniform ice density of $917 \mathrm{~kg} \mathrm{~m}^{3}$ (Cuffey \& Paterson, 2010). A parabolic bed shape nearly equal to the bathymetry observations in the Crane fjord near the terminus (Rebesco et al., 2014) is used to estimate flux gate cross-sectional area from the centerline thickness. Time series for $F_{g l}$ and the calving front position are shown for the unperturbed scenario and the maximum perturbation model runs for each parameter in addition to observations from Rignot et al. (2004) and Dryak \& Enderlin (2020) in Figure 4.3.

\subsection{Submarine Melt Rate}

The sensitivity tests show that perturbations in submarine melt have the largest impact on glacier thickness and flow speed near the terminus (Fig. 4.1). For every 1 $\mathrm{m} \mathrm{a}^{-1}$ increase in submarine melt by 2100 , the glacier length decreases by $0.5-1.7 \mathrm{~km}$ and the grounding line thickness decreases by 0-7 m (Table 4.1). As the magnitude in

submarine melt perturbation increases, the thickness and speed near the floating ice 
tongue decrease non-linearly, likely because retreat and thinning of the floating ice tongue decreases the surface area exposed to submarine melt. Under the maximum melt scenario, the grounding line position is $\sim 1 \mathrm{~km}$ retracted and the grounding line speed is $65 \mathrm{~m} \mathrm{a}^{-1}$ or $\sim 15 \%$ greater than the unperturbed scenario. The slight increase in speed under the $-10 \mathrm{~m} \mathrm{a}^{-1}$ submarine melt perturbation perturbation slightly over-compensates for the decrease in thickness, leading to an increase in mass discharge at the grounding line of $0.07 \mathrm{Gt} \mathrm{a}^{-1}$ relative to the unperturbed scenario and a total of $0.98 \mathrm{Gt} \mathrm{a}^{-1}$ by 2100 (Fig. 4.2). Throughout the maximum melt scenario, $F_{g l}$ decreases rapidly from 2009 through 2020, then begins to slightly increase until 2100 (Fig. 4.3). The terminus position continues to advance substantially from 2009 until about 2040, after which it begins to retreat slightly by $\sim 0.05 \mathrm{~km}$ per decade until 2100. Overall, the glacier length, speed, thickness, and $F_{g l}$ change by $\sim 1 \%$ or less with respect to the unperturbed scenario for all submarine melt perturbations. 

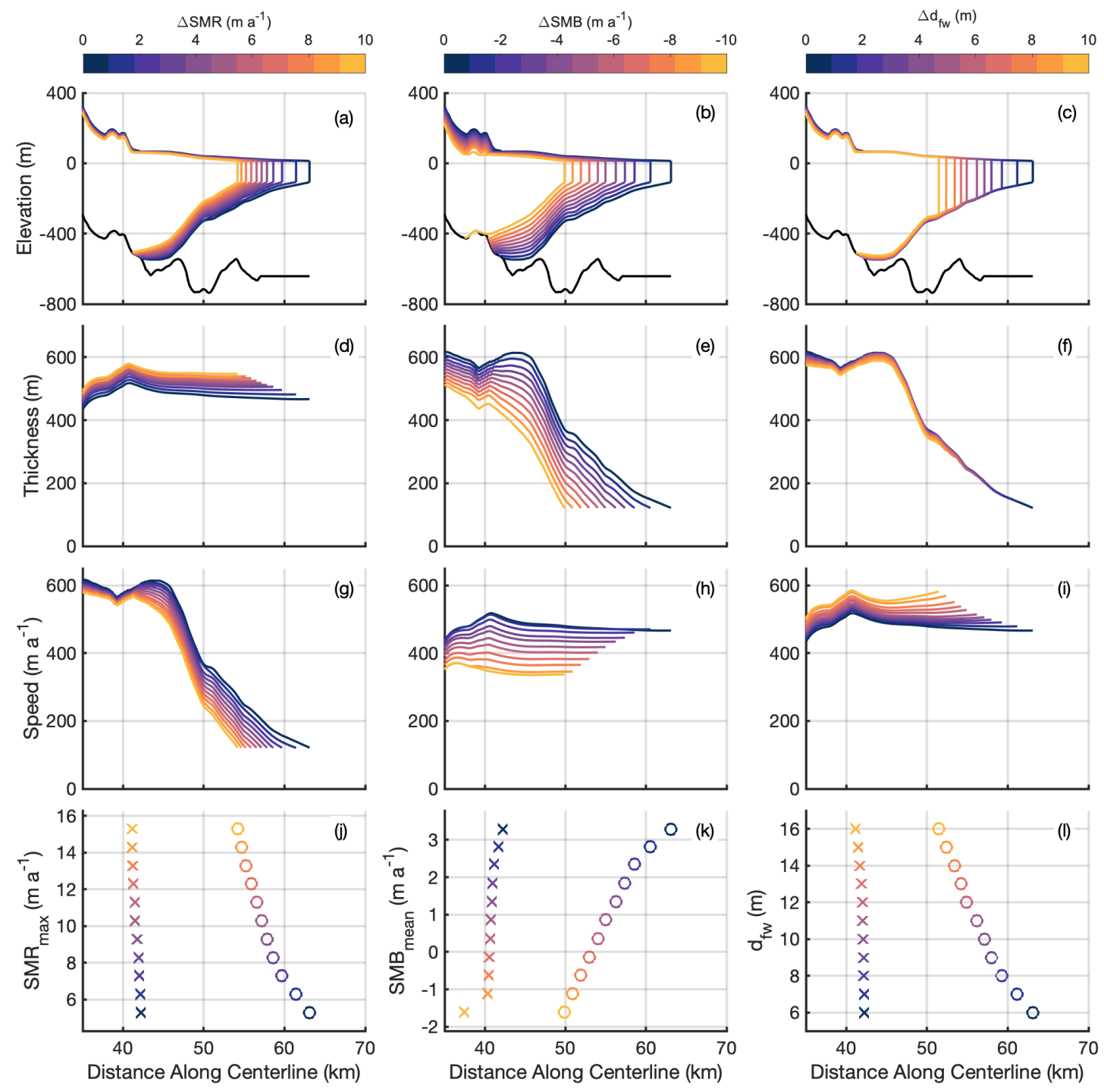

Figure 4.1: Results of model sensitivity tests in year 2100 for (first column) the submarine melt rate ( $\triangle \mathrm{SMR}$ ), (second column) the surface mass balance $(\triangle \mathrm{SMB})$, and (third column) the fresh water depth in crevasses $\left(\Delta d_{f w}\right)$. (a-c) The resulting glacier geometry, (d-f) thickness, (g-i) speed, and $(\mathrm{j}-\mathrm{l})$ changes in grounding line (crosses) and calving front positions (circles) are shown with respect to the unperturbed scenario, shown in dark purple. Note that warmer colors indicate increased melting, positive $\Delta$ SMR and $\Delta d_{f w}$ values indicate increased melting, and positive $\Delta$ SMB values indicate decreased melting or increased accumulation. 
Table 4.1: Results for the submarine melt sensitivity tests at the final model year 2100, where $\Delta$ SMR is the maximum submarine melt perturbation with respect to the unperturbed scenario, $\Delta L$ is the change in modeled glacier length, $\Delta x_{g l}$ is change in the grounding line position along the centerline, and $\Delta H_{g l}, \Delta U_{g l}$, and $F_{g l}$ are the glacier thickness, speed, and mass discharge at the grounding line, respectively.

\begin{tabular}{|c|c|c|c|c|c|}
\hline $\begin{array}{l}\Delta \text { SMR } \\
\left(\mathrm{m} \mathrm{a}^{-1}\right)\end{array}$ & $\Delta L(\mathbf{k m})$ & $\Delta x_{g l}(\mathrm{~km})$ & $\Delta H_{g l}(\mathbf{m})$ & $\begin{array}{c}\Delta U_{g l}(\mathbf{m} \\
\left.\mathbf{a}^{-1}\right)\end{array}$ & $\begin{array}{c}F_{g l}(\mathbf{G t} \\
\left.\mathbf{a}^{-1}\right)\end{array}$ \\
\hline 0 & 0.0 & 0.0 & 0 & 0 & 0.91 \\
\hline 1 & -1.7 & -0.1 & -4 & 10 & 0.92 \\
\hline 2 & -3.4 & -0.2 & -7 & 19 & 0.94 \\
\hline 3 & -4.5 & -0.2 & -10 & 28 & 0.95 \\
\hline 4 & -5.3 & -0.4 & -16 & 35 & 0.95 \\
\hline 5 & -5.9 & -0.7 & -23 & 43 & 0.95 \\
\hline 6 & -6.6 & -0.7 & -23 & 49 & 0.96 \\
\hline 7 & -7.2 & -0.9 & -28 & 58 & 0.97 \\
\hline 8 & -7.9 & -1.0 & -32 & 64 & 0.98 \\
\hline 9 & -8.4 & -1.1 & -34 & 59 & 0.96 \\
\hline 10 & -8.9 & -1.1 & -35 & 70 & 0.98 \\
\hline
\end{tabular}

\subsection{Surface Mass Balance}

The sensitivity test results show that perturbations in SMB lead to the most substantial changes in the glacier interior and in the mass discharge relative to other parameter perturbations (Figs. 4.1 and 4.2). The impacts on the interior thickness and speed are unsurprising given that only SMB perturbations are directly applied inland of the floating ice tongue. Although the grounding line position remains fairly steady under most perturbations, surface thinning and deceleration are the most substantial at the floating ice tongue in response to increases in the SMB gradient. For each additional $1 \mathrm{~m} \mathrm{a}^{-1}$ decrease in SMB by 2100, the glacier length decreases by 1.0-2.5 km, the grounding line position decreases by $0-2.8 \mathrm{~km}$, the grounding line thickness decreases by $\sim 3-18 \mathrm{~m}$, and the grounding line speed changes by up to $23 \mathrm{~m}$ 
$\mathrm{a}^{-1}$ compared to the unperturbed scenario (Table 4.2). Changes in glacier thickness, speed, and length in response to increased magnitudes in the SMB perturbation are nearly linear, contrary to other parameter perturbations. The grounding line retreats by small but slightly increasing distances with decreasing SMB, with a pronounced retreat in position and increase in discharge as the grounding line retreats from the prograde bed slope (i.e., bed elevation decreases in the flow direction) into a slightly over-deepened, retrograde slope (i.e., bed elevation increases in the flow direction) in response to the largest $\mathrm{SMB}$ perturbation. For the $-10 \mathrm{~m} \mathrm{a}^{-1} \Delta \mathrm{SMB}$ scenario, $F_{g l}$ decreases rapidly until about model year 2020, then continues to steadily decrease to $0.56 \mathrm{Gt} \mathrm{a}^{-1}$ by $2100,0.35 \mathrm{Gt} \mathrm{a}^{-1}$ lower than the unperturbed scenario (Fig. 4.3). There is a slight increase in discharge in $\sim 2097$ as the grounding line retreats past the retrograde slope, followed by a continued decreasing trend in discharge as the grounding line regrounds on the prograde slope near $42 \mathrm{~km}$ along the centerline. The terminus position on the other hand advances until about 2040, then retreats steadily until 2100 by an average of $0.1 \mathrm{~km}$ per decade.

\subsection{Fresh Water in Crevasses}

The results for the fresh water depth in crevasses perturbations show the most substantial changes in flow speed concentrated at the floating ice tongue (Fig. 4.1g-i). There is a direct relationship between the glacier length and changes in $d_{f w}$, although the grounding line position remains stable for all scenarios. Similar to the submarine melt rate scenarios, higher melt perturbations impact the length of the floating ice tongue, with decreasing length under higher melt scenarios. However, perturbations in $d_{f w}$ do not significantly impact glacier thickness and lead to increases in speed at 
Table 4.2: Results for the surface mass balance sensitivity tests at the final model year 2100, where $\Delta$ SMB is the maximum SMB perturbation with respect to the unperturbed scenario, $\Delta L$ is the change in modeled glacier length, $\Delta x_{g l}$ is change in the grounding line position along the centerline, and $\Delta H_{g l}, \Delta U_{g l}$, and $F_{g l}$ are the glacier thickness, speed, and mass discharge at the grounding line, respectively.

\begin{tabular}{|c|c|c|c|c|c|}
\hline $\begin{array}{c}\Delta \mathbf{S M B} \\
\left(\mathbf{m ~ \mathbf { a } ^ { - 1 }}\right)\end{array}$ & $\Delta L(\mathbf{k m})$ & $\Delta x_{g l}(\mathbf{k m})$ & $\Delta H_{g l}(\mathbf{m})$ & $\begin{array}{c}U_{g l}(\mathbf{m} \\
\left.\mathbf{a}^{-1}\right)\end{array}$ & $\begin{array}{c}F_{g l}(\mathbf{G t} \\
\left.\mathbf{a}^{-1}\right)\end{array}$ \\
\hline 0 & 0.0 & 0.0 & 0 & 0 & 0.91 \\
-1 & -2.5 & -0.5 & -18 & -1 & 0.89 \\
-2 & -4.5 & -1.1 & -35 & -11 & 0.84 \\
-3 & -5.7 & -1.2 & -47 & -29 & 0.80 \\
-4 & -6.8 & -1.3 & -59 & -43 & 0.76 \\
-5 & -8.1 & -1.5 & -70 & -63 & 0.71 \\
-6 & -9.1 & -1.5 & -82 & -82 & 0.66 \\
-7 & -10.1 & -1.6 & -95 & -105 & 0.61 \\
-8 & -11.2 & -1.7 & -109 & -125 & 0.57 \\
-9 & -12.2 & -1.9 & -125 & -148 & 0.52 \\
-10 & -13.2 & -4.7 & -128 & -140 & 0.56 \\
\hline
\end{tabular}

the floating ice tongue, contrary to the decreased speeds under increased submarine melt and thinning of the floating ice tongue under decreased SMB. For the maximum $d_{f w}$ increase of $10 \mathrm{~m}$, the calving front retreats by $\sim 10.7 \mathrm{~km}$ while the grounding line retreats by $0.9 \mathrm{~km}$, the grounding line thickness decreases by $30 \mathrm{~m}$, and the grounding line speed increases by $80 \mathrm{~m} \mathrm{a}^{-1}$ with respect to the unperturbed scenario. Contrary in part to SMB perturbations, changes in the glacier flow speed increase non-linearly in response to increased $d_{f w}$ potentially because there is no substantial surface thinning and the calving front thickens as it retreats, removing resistance at the glacier front and increasing the flow speed. Similar to other parameter perturbations, the terminus position rapidly advances before retreating steadily by $\sim 0.02 \mathrm{~km}$ per decade under the maximum $d_{f w}$ scenario (Fig. 4.3). Following deceleration and decreasing discharge 


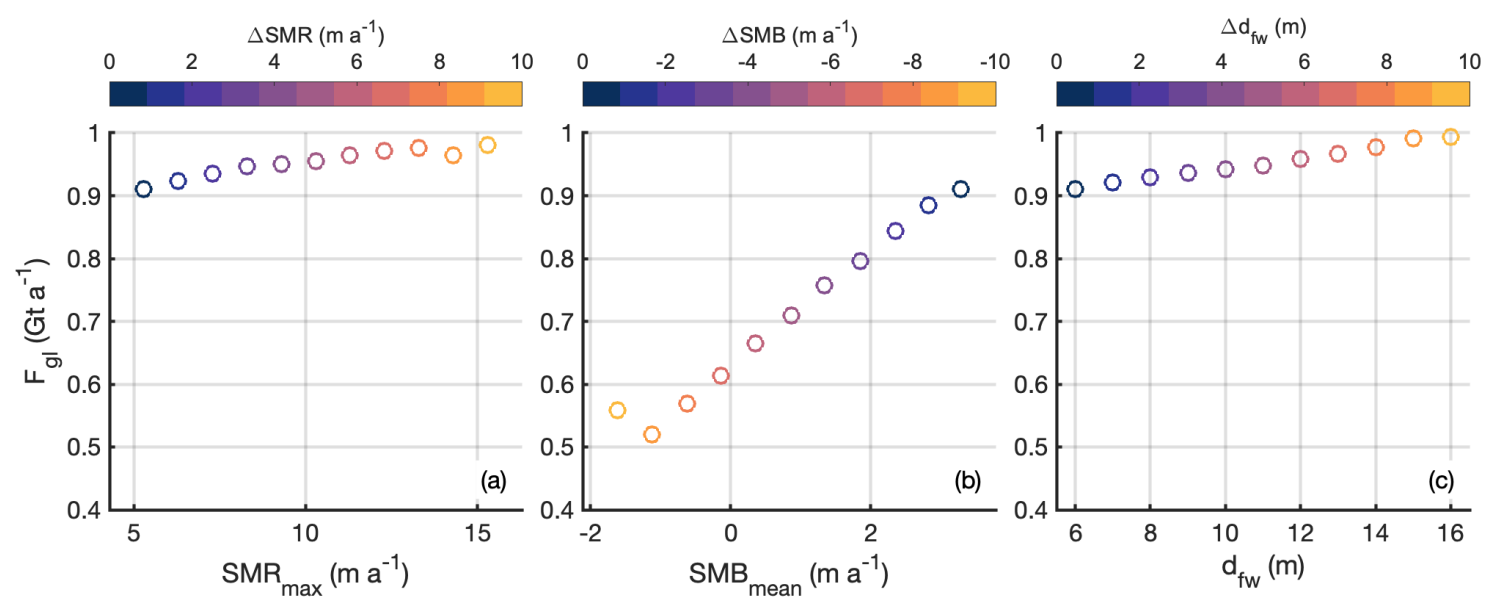

Figure 4.2: Glacier mass discharge across the grounding line $\left(F_{g l}\right)$ in model year 2100 resulting from each of the perturbation scenarios. $F_{g l}$ from each scenario is plotted for a) maximum submarine melt rate $\left(S M R_{\max }\right)$, b) mean surface mass balance $\left(S M B_{\text {mean }}\right)$, and c) fresh water depth in crevasses $\left(d_{f w}\right)$. Colors represent the change in each variable with respect to the unperturbed scenario, where warmer colors signify higher melt scenarios.

between 2009 and 2020, the increased grounding line speed outweighs the decrease in grounding line thickness, leading to slight and steady increases in $F_{g l}$ to $0.95 \mathrm{Gt} \mathrm{a}^{-1}$ by 2100 , which is $0.03 \mathrm{Gt} \mathrm{a}^{-1}$ higher than the unperturbed scenario. 


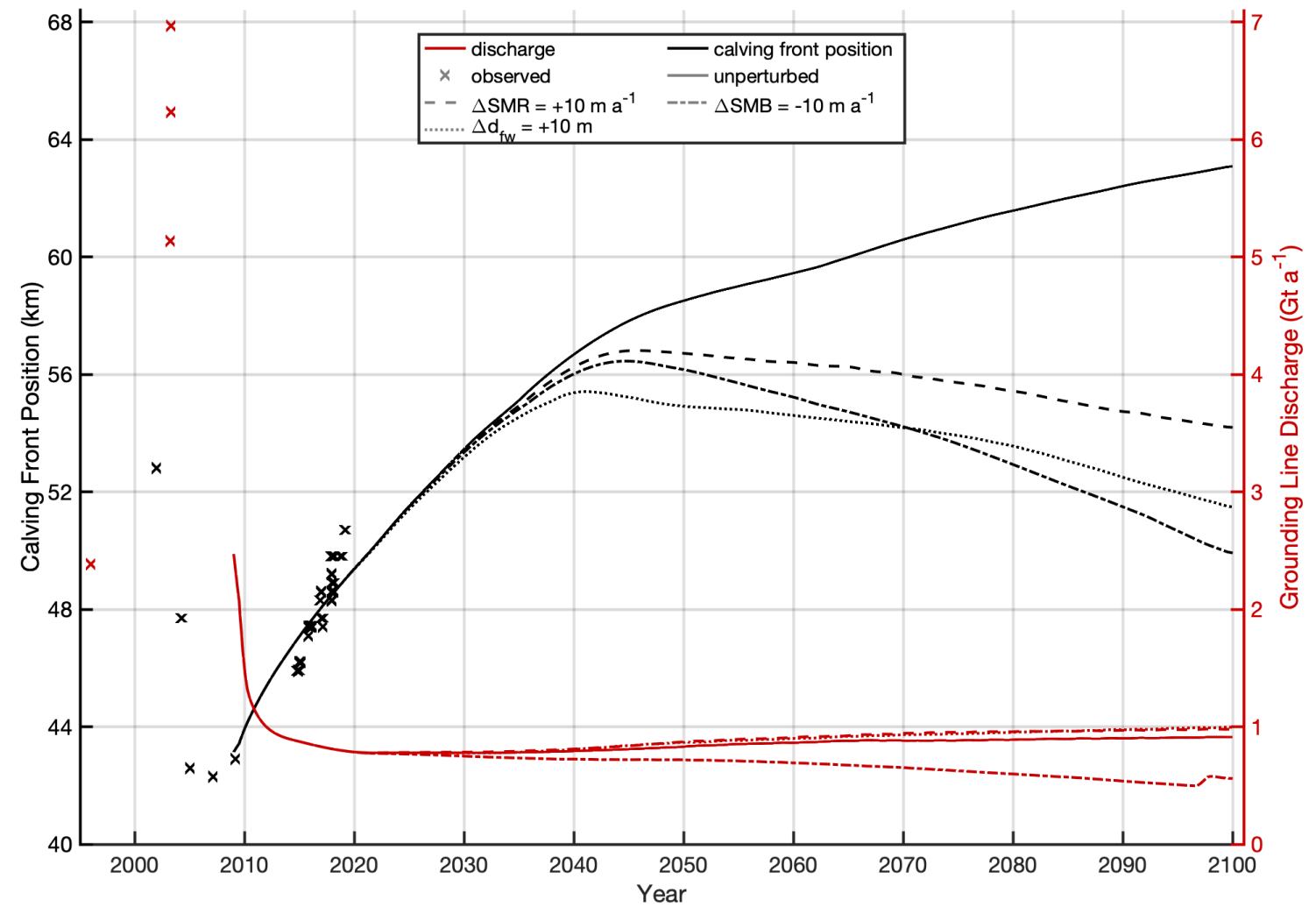

Figure 4.3: Time series of Crane Glacier observed and modeled calving front position along the centerline (black) and mass discharge across the grounding line (red). Observed discharge estimates (red crosses) are from Rignot et al. (2004) and observed calving front positions (black crosses) are from Dryak \& Enderlin (2020). Different climate perturbation scenarios are distinguished by line type, including the unperturbed scenario and the maximum melt scenarios for the submarine melt $(\triangle \mathrm{SMR}=+10 \mathrm{~m}$ $\left.\mathrm{a}^{-1}\right)$, the surface mass balance $\left(\triangle \mathrm{SMB}=-10 \mathrm{~m} \mathrm{a}^{-1}\right)$, and calving due to hydrofracturing $\left(\Delta d_{f w}=+10 \mathrm{~m}\right)$, averaged over one-year bins. 
Table 4.3: Results for the freshwater in crevasses sensitivity tests at the final model year 2100, where $\Delta d_{f w}$ is the maximum freshwater depth perturbation with respect to the unperturbed scenario, $\Delta L$ is the change in modeled glacier length, $\Delta x_{g l}$ is change in the grounding line position along the centerline, and $\Delta H_{g l}, \Delta U_{g l}$, and $F_{g l}$ are the glacier thickness, speed, and mass discharge at the grounding line, respectively.

\begin{tabular}{|c|c|c|c|c|c|}
\hline$\Delta d_{f w}(\mathbf{m})$ & $\Delta L \mathbf{( k m})$ & $\Delta x_{g l}(\mathbf{k m})$ & $\Delta H_{g l}(\mathbf{m})$ & $\begin{array}{c}U_{g l}(\mathbf{m} \\
\left.\mathbf{a}^{-1}\right)\end{array}$ & $\begin{array}{c}F_{g l} \mathbf{( G t} \\
\left.\mathbf{a}^{-1}\right)\end{array}$ \\
\hline 0 & 0.0 & 0.0 & 0 & 0 & 0.91 \\
1 & -1.9 & -0.0 & -1 & 7 & 0.92 \\
2 & -3.8 & -0.0 & -2 & 12 & 0.93 \\
3 & -5.1 & -0.1 & -3 & 16 & 0.94 \\
4 & -6.0 & -0.1 & -5 & 21 & 0.94 \\
5 & -6.9 & -0.2 & -7 & 26 & 0.95 \\
6 & -8.2 & -0.2 & -9 & 34 & 0.96 \\
7 & -8.9 & -0.3 & -13 & 42 & 0.97 \\
8 & -9.7 & -0.5 & -18 & 51 & 0.98 \\
9 & -10.7 & -0.8 & -24 & 65 & 0.99 \\
10 & -11.6 & -1.0 & -32 & 74 & 0.99 \\
\hline
\end{tabular}




\section{CHAPTER 5:}

\section{DISCUSSION}

\subsection{Model Response to Climate Perturbations}

The model simulations show that changes in submarine melting, surface melt water runoff, and crevasse hydrofracture result in unique changes in glacier dynamics. Increased submarine melting causes flow speeds and discharge to increase slightly through thinning of the floating ice tongue, which removes resistance at the ocean margin. In contrast, increased melt on the glacier surface generally decreases the driving stress through widespread thinning, which causes reductions in flow speed and discharge across the grounding line under nearly all SMB perturbations. If atmospheric warming increases the depth of impounded water in crevasses (i.e., larger $\left.d_{f w}\right)$ without increasing runoff, retreat of the floating ice tongue and a reduction in resistive stress at the terminus has the opposite influence: speeds and discharge increase. Despite differences in thinning, increased melt in crevasses (through increased $\left.d_{f w}\right)$ or at the base of the ice tongue (through increased submarine melt) by the same magnitude leads to nearly equivalent increases in discharge.

Importantly, however, there are marked differences in terminus position and grounding line stability for the different climate perturbations. The magnitude of acceleration and terminus retreat is comparable whether an increase in surface melting leads 
to an increase in annual melt water runoff or the equivalent deepening of crevasses, and exceeds that driven by an equivalent increase in submarine melting with minimal impact on grounding line stability. More broadly, the sensitivity tests suggest that Crane Glacier is largely insensitive to submarine melt rate based on the nearly unchanged grounding line position and the less than 10\% change in discharge under the maximum submarine melt scenario of $+10 \mathrm{~m} \mathrm{a}^{-1}$ by 2100 . Unlike the former Larsen A and B and present day Larsen C ice shelves (McGrath et al., 2012; Luckman et al., 2014), changes in the length and thickness of the floating ice tongue have minimal impact on glacier discharge, suggesting that Crane's future mass loss will remain independent of ocean temperatures in coming years. Additionally, surface thinning in response to decreased SMB will have the largest impact on mass loss in years to come (Fig. 4.2), decreasing the surface elevation and the discharge by up to $40 \%$ with respect to the unperturbed scenario. The grounding line remains fairly stable unless the magnitude of surface thinning enables retreat of the grounding line onto an over-deepened, retrograde bed slope. Once reaching this retrograde slope, the grounding line rapidly retreats and discharge increases until the glacier regrounds on the retracted prograde bed slope. In contrast, changes in hydrofracture-induced calving by means of the $d_{f w}$ impact the length of the floating ice tongue yet lead to very little change in discharge. Given the magnitude differences in discharge under each parameter perturbation and the increasing surface temperatures projected on the AP (Siegert et al., 2019), I infer that the the impacts of surface thinning at Crane will outweigh the impacts of melt water impounded in crevasses or increased submarine melt, ultimately leading to a decrease in discharge in the coming century. 


\subsection{Glacier Response to Ice Shelf Collapse}

The results of the modeling experiments suggest that (1) former tributary glaciers can take several decades to geometrically adjust to ice shelf collapse and that (2) the growth of a floating ice tongue at the ocean margin serves as a buffer to enhanced flow for glaciers following ice shelf collapse, allowing the grounding zone to thicken and to remain relatively stable or to advance into slightly deeper waters (Fig. 4.1). In recent years, mass loss has increased for glaciers in West Antarctica (Mouginot et al., 2014) and the Larsen A embayment (Seehaus et al., 2015), including a 140\% increase on the AP in 2006 (Rignot et al., 2008), which may continue in the future (Siegert et al., 2019). Observations from Rignot et al. (2004) revealed substantial acceleration in glacier mass discharge from several former tributaries following the Larsen B ice shelf collapse, increasing at Crane Glacier nearly threefold from $2.5 \mathrm{~km} \mathrm{a}^{-1}\left(\sim 2.4 \mathrm{Gt} \mathrm{a}^{-1}\right)$ in 1996 to $7.6 \mathrm{~km} \mathrm{a}^{-1}\left(\sim 7.0 \mathrm{Gt} \mathrm{a}^{-1}\right)$ in 2003 while the calving front rapidly retreated (Dryak \& Enderlin, 2020), shown in Figure 4.3. My model simulations suggest that discharge at the grounding line will decrease in coming decades under all scenarios relative to rates immediately before and after the Larsen B ice shelf collapse in early 2002. Under all scenarios, discharge decreases from $\sim 2.8 \mathrm{Gt} \mathrm{a}^{-1}$ to $0.53-0.96 \mathrm{Gt} \mathrm{a}^{-1}$ by 2100, representing a 66-81\% decrease in discharge between 2009 and 2100. In addition, the speed and surface elevation stabilize by 2020 after nearly two decades of rapid changes in speed and geometry.

After 2020, the glacier surface elevation, speed, and grounding line position remain nearly constant when the grounding line stabilizes on a prograde slope $\sim 40-42 \mathrm{~km}$

along the centerline in the unperturbed scenario. A prograde bed slope has been shown to generally hinder rapid retreat or advance of the grounding line position, as 
opposed to a retrograde bed slope, which can decrease stability of the grounding zone (Schoof, 2007; Enderlin et al., 2013a; Catania et al., 2018; Morlighem et al., 2020). For decades following 2020, a floating ice tongue forms and gradually increases in length (Fig. 4.3). The continued advance of the glacier under all climate forcing scenarios suggests that its recent and near-future (i.e., next several decades) dynamic behavior is primarily in response to the Larsen B ice shelf collapse and is largely independent of climate, analogous to the advancing stage of the tidewater glacier cycle. Interestingly, this advance occurs despite the exclusion of grounding line shoal progradation in our model. Previous work has shown that advancing phase of the tidewater glacier cycle is strongly controlled by sedimentation at the glacier bed (Nick et al., 2007a; Brinkerhoff et al., 2017). Sediment cores acquired from Crane fjord suggest sedimentation rates are on the order of meters per year seaward of the grounding line (Rebesco et al., 2014), but shoal formation is not apparent in the 20162018 near-terminus radar-derived bed elevation profiles from NASA OIB. However, neither dataset crosses the grounding line, so the presence or absence of a shoal cannot be confidently determined. It is possible that the presence of a shoal would allow the glacier to continue to advance into deeper water and over a longer time period than simulated here. However, the continued advance of the modeled glacier in the absence of a prograding shoal suggests that, unlike tidewater glaciers, sediment shoals may not be required for glaciers with floating termini to re-advance and stabilize following rapid shelf retreat. Instead, the floating ice tongue generates sufficient flow resistance to promote grounding zone thickening and gradual re-advance. 


\subsection{Potential Biases}

The relative insensitivity of Crane Glacier to climate forcing suggested by the model experiments is dependent on several assumptions: (1) all surface melt water currently and continues to run off, (2) basal lubrication does not vary with increased surface melt, (3) perturbations in floating ice tongue submarine melt and crevasse hydrofracture are uniform and constant, and (4) climate perturbations occur independently. In addition to biases associated with the statistical downscaling method (Noël et al., 2016), the aforementioned elevation bias in the RACMO2.3 SMB product (Van Wessem et al., 2016) likely leads to an under-estimation of air temperatures, melt water production, and melt water runoff. Further, the climate perturbations executed for the sensitivity tests do not change temporally and therefore do not account for seasonal to interannual patterns which may impact local glacier dynamics. As previous research has shown, precipitation on the AP has pronounced seasonality (Van Wessem et al., 2016). Other seasonal atmospheric events, such as foehn winds, melt water pooling or drainage patterns, or the strength and frequency of westerly winds, for example, can impact firn evolution on the ice surface, accumulation, and surface melt for glaciers on the AP (Tuckett et al., 2019; Datta et al., 2019). However, recent observations at Crane show that although the surface speeds and terminus position may change on a monthly basis, the magnitudes of change are within the uncertainty of observations and the long-term deceleration and terminus advance in recent years are much larger in magnitude than seasonal variations (Dryak \& Enderlin, 2020). Thus, I suggest that any changes in glacier speed and geometry in response to seasonal climate conditions may be reasonably ignored for the purposes of this study. 


\subsection{Conclusions and Future Work}

Through this work, I have developed a modeling workflow to assess tributary glacier response to ice shelf collapse and subsequent sensitivity to future changes in atmospheric and oceanic thermal forcing at Crane Glacier, eastern AP. By executing model parameter sensitivity tests, I suggest that Crane will remain largely independent of climate in coming years, analogous to the advancing stage of the tidewater glacier cycle. Under all simulations, the glacier mass discharge rapidly decreases from 2.1 Gt a $\mathrm{a}^{-1}$ until about 2020, after which it reaches near a steady state, suggesting that tributary glaciers can take several decades to geometrically adjust to ice shelf collapse. By 2100, the modeled discharge is 0.53-0.96 Gt $\mathrm{a}^{-1}$, with the most substantial thinning and decrease in discharge shown in the maximum SMB perturbation. Additionally, the growth of a floating ice tongue allows the grounding zone to remain relatively steady as the calving front advances under all climate scenarios.

Given the morphological evidence for subglacial sedimentation at Crane (Rebesco et al., 2014), future work may include the implementation of a sedimentation model in place of a static bed geometry. Although the floating ice tongue supports a stable grounding zone, a progading sediment shoal may shield the glacier from submarine melt and enable advance into deeper water. To increase our understanding of regional ice dynamics, the modeling workflow should also be applied to other former tributary glaciers of the Larsen A and B ice shelves (Fig. 1.1) to investigate the influence of geometry, for example, on glacier sensitivity to climate forcing following ice shelf collapse.

All code developed for observations synthesis and model execution is accessible as a GitHub repository (https://github.com/RaineyAbe/CraneGlacier_flowlinemodeling). 


\section{REFERENCES}

Adusumilli, Susheel, Fricker, Helen Amanda, Siegfried, Matthew R., Padman, Laurie, Paolo, Fernando S., \& Ligtenberg, Stefan R.M. 2018. Variable Basal Melt Rates of Antarctic Peninsula Ice Shelves, 1994-2016. Geophysical Research Letters, 45(9), 4086-4095.

Adusumilli, Susheel, Fricker, Helen Amanda, Medley, Brooke, Padman, Laurie, \& Siegfried, Matthew R. 2020. Interannual variations in meltwater input to the Southern Ocean from Antarctic ice shelves. Nature Geoscience, 13(9), 616-620.

Amaral, Tristan, Bartholomaus, Timothy C., \& Enderlin, Ellyn M. 2020. Evaluation of Iceberg Calving Models Against Observations From Greenland Outlet Glaciers. Journal of Geophysical Research: Earth Surface, 125(6), 1-29.

Amundson, Jason M. 2016. A mass-flux perspective of the tidewater glacier cycle. Journal of Glaciology, 62(231), 82-93.

Auger, Matthis, Morrow, Rosemary, Kestenare, Elodie, \& Sallée, Jean-Baptiste. 2020. Southern Ocean in-situ temperature trends over 25 years emerge from interannual variability. Nature Communications, 1-9.

Benn, Douglas I., Warren, Charles R., \& Mottram, Ruth H. 2007. Calving processes and the dynamics of calving glaciers. Earth-Science Reviews, 82(3-4), 143-179. 
Berthier, Etienne, Scambos, Ted A., \& Shuman, Christopher A. 2012. Mass loss of Larsen B tributary glaciers (Antarctic Peninsula) unabated since 2002. Geophysical Research Letters, 39(13).

Borstad, C. P., Khazendar, A., Larour, E., Morlighem, M., Rignot, E., Schodlok, M. P., \& Seroussi, H. 2012. A damage mechanics assessment of the Larsen B ice shelf prior to collapse: Toward a physically-based calving law. Geophysical Research Letters, 39(17), 1-5.

Brinkerhoff, Douglas, Truffer, Martin, \& Aschwanden, Andy. 2017. Sediment transport drives tidewater glacier periodicity. Nature Communications, 8(1).

Catania, G. A., Stearns, L. A., Sutherland, D. A., Fried, M. J., Bartholomaus, T. C., Morlighem, M., Shroyer, E., \& Nash, J. 2018. Geometric Controls on Tidewater Glacier Retreat in Central Western Greenland. Journal of Geophysical Research: Earth Surface, 123(8), 2024-2038.

Choi, Y., Morlighem, M., Wood, M., \& Bondzio, J. H. 2018. Comparison of four calving laws to model Greenland outlet glaciers. The Cryosphere, 12(12), 37353746.

Christianson, Knut, Bushuk, Mitchell, Dutrieux, Pierre, Parizek, Byron R., Joughin, Ian R., Alley, Richard B., Shean, David E., Abrahamsen, E. Povl, Anandakrishnan, Sridhar, Heywood, Karen J., Kim, Tae-Wan, Lee, Sang Hoon, Nicholls, Keith, Stanton, Tim, Truffer, Martin, Webber, Benjamin G. M., Jenkins, Adrian, Jacobs, Stan, Bindschadler, Robert, \& Holland, David M. 2016. Sensitivity of Pine Island Glacier to observed ocean forcing. Geophysical Research Letters, 43(20), 10,81710,825 . 
Colgan, W., Pfeffer, W. T., Rajaram, H., Abdalati, W., \& Balog, J. 2012. Monte Carlo ice flow modeling projects a new stable configuration for Columbia Glacier, Alaska, c. 2020. Cryosphere, 6(6), 1395-1409.

Cook, A. J., Holland, P. R., Meredith, M. P., Murray, T., Luckman, A., \& Vaughan, D. G. 2016. Ocean forcing of glacier retreat in the western Antarctic Peninsula. Science, 353(6296), 283-286.

Cook, S., Zwinger, T., Rutt, I. C., O'Neel, S., \& Murray, T. 2012. Testing the effect of water in crevasses on a physically based calving model. Annals of Glaciology, 53(60), 90-96.

CReSIS. 2020. CReSIS Toolbox MATLAB.

Cuffey, K., \& Paterson, W. S. B. 2010. The physics of glaciers. ButterworthHeinemann/Elsevier.

Datta, Rajashree Tri, Tedesco, Marco, Fettweis, Xavier, Agosta, Cecile, Lhermitte, Stef, Lenaerts, Jan T.M., \& Wever, Nander. 2019. The Effect of Foehn-Induced Surface Melt on Firn Evolution Over the Northeast Antarctic Peninsula. Geophysical Research Letters, 46(7), 3822-3831.

Doake, C S M, \& Vaughan, D G. 1991. Rapid disintegration of the Wordie Ice Shelf in response to atmospheric warming. Nature, 350(6316), 328-330.

Dryak, M C, \& Enderlin, E M. 2020. Analysis of Antarctic Peninsula glacier frontal ablation rates with respect to iceberg melt-inferred variability in ocean conditions. Journal of Glaciology. 
Dutrieux, Pierre, De Rydt, Jan, Jenkins, Adrian, Holland, Paul R., Ha, Ho Kyung, Lee, Sang Hoon, Steig, Eric J., Ding, Qinghua, Abrahamsen, E. Povl, \& Schröder, Michael. 2014. Strong Sensitivity of Pine Island Ice-Shelf Melting to Climatic Variability. Science, 343(6167), 174-178.

Enderlin, E. M., Howat, I. M., \& Vieli, A. 2013a. High sensitivity of tidewater outlet glacier dynamics to shape. Cryosphere, 7(3), 1007-1015.

Enderlin, E. M., Howat, I. M., \& Vieli, A. 2013b. The sensitivity of flowline models of tidewater glaciers to parameter uncertainty. The Cryosphere, 7(10), 1579-1590.

Fahrbach, Eberhard, Hoppema, Mario, Rohardt, Gerd, Schröder, Michael, \& Wisotzki, Andreas. 2004. Decadal-scale variations of water mass properties in the deep Weddell Sea. Ocean Dynamics, 54(1), 77-91.

Favier, L, Durand, G, Cornford, S L, Gudmundsson, G H, Gagliardini, O, GilletChaulet, F, Zwinger, T, Payne, A J, \& Le Brocq, A M. 2014. Retreat of Pine Island Glacier controlled by marine ice-sheet instability. Nature Climate Change, 4(2), 117-121.

Felikson, Denis, Bartholomaus, Timothy C, Catania, Ginny A, Korsgaard, Niels J, Kjær, Kurt H, Morlighem, Mathieu, Noël, Brice, van den Broeke, Michiel, Stearns, Leigh A, Shroyer, Emily L, Sutherland, David A, \& Nash, Jonathan D. 2017. Inland thinning on the Greenland ice sheet controlled by outlet glacier geometry. Nature Geoscience, 10(5), 366-369.

Felikson, Denis, A. Catania, Ginny, Bartholomaus, Timothy C., Morlighem, Mathieu, 
\& Noël, Brice P.Y. 2021. Steep Glacier Bed Knickpoints Mitigate Inland Thinning in Greenland. Geophysical Research Letters, 48(2), 1-10.

Friedl, Peter, Seehaus, Thorsten C., Wendt, Anja, Braun, Matthias H., \& Höppner, Kathrin. 2018. Recent dynamic changes on Fleming Glacier after the disintegration of Wordie Ice Shelf, Antarctic Peninsula. Cryosphere, 12(4), 1347-1365.

Gardner, A. S., Fahnestock, M. A., \& Scambos., T. A. 2020. ITS_LIVE Regional Glacier and Ice Sheet Velocities.

Glen, J. W. 1955. The creep of polycrystalline ice. Proceedings of the Royal Society, 225, $519-538$.

Gogineni, S., Tammana, D., Braaten, D., Leuschen, C., Akins, T., Legarsky, J., Kanagaratnam, P., Stiles, J., Allen, C., \& Jezek, K. 2001. Coherent radar ice thickness measurements over the Greenland ice sheet. Journal of Geophysical Research: Atmospheres, 106(D24), 33761-33772.

Gwyther, David E, O’Kane, Terence J, Galton-Fenzi, Benjamin K, Monselesan, Didier P, \& Greenbaum, Jamin S. 2018. Intrinsic processes drive variability in basal melting of the Totten Glacier Ice Shelf. Nature Communications, 9(1), 3141.

Hock, Regine, De Woul, Mattias, Radic, Valentina, \& Dyurgerov, Mark. 2009. Mountain glaciers and ice caps around Antarctica make a large sea-level rise contribution. Geophysical Research Letters, 36(7), 1-5.

Howat, I. M., Porter, C., Smith, B. E., Noh, M.-J., \& Morin, P. 2019. The Reference Elevation Model of Antarctica. The Cryosphere, 13(2), 665-674. 
Howat, Ian M., Smith, Ben E., Joughin, Ian, \& Scambos, Ted A. 2008. Rates of southeast Greenland ice volume loss from combined ICESat and ASTER observations. Geophysical Research Letters, 35(17), 1-5.

Jamieson, Stewart S R, Vieli, Andreas, Livingstone, Stephen J, Cofaigh, Colm Ó, Stokes, Chris, Hillenbrand, Claus-Dieter, \& Dowdeswell, Julian A. 2012. Ice-stream stability on a reverse bed slope. Nature Geoscience, 5(11), 799-802.

Jenkins, Adrian. 2011. Convection-driven melting near the grounding lines of ice shelves and tidewater glaciers. Journal of Physical Oceanography, 41(12), 22792294.

Jenkins, Adrian, Dutrieux, Pierre, Jacobs, Stanley S, McPhail, Stephen D, Perrett, James R, Webb, Andrew T, \& White, David. 2010. Observations beneath Pine Island Glacier in West Antarctica and implications for its retreat. Nature Geoscience, 3(7), 468-472.

Joughin, Ian, Abdalati, Waleed, \& Fahnestock, Mark. 2004. Large fluctuations in speed on Greenland's Jakobshavn Isbræ glacier. Nature, 432(7017), 608-610.

Joughin, Ian, Smith, Benjamin E., \& Medley, Brooke. 2014. Marine Ice Sheet Collapse Potentially Under Way for the Thwaites Glacier Basin, West Antarctica. Science, 344(6185), 735-738.

Kyrke-Smith, Teresa M., Gudmundsson, G. Hilmar, \& Farrell, Patrick E. 2018. Relevance of Detail in Basal Topography for Basal Slipperiness Inversions: A Case Study on Pine Island Glacier, Antarctica. Frontiers in Earth Science, 6, 33. 
Larour, E., Seroussi, H., Morlighem, M., \& Rignot, E. 2012. Continental scale, high order, high spatial resolution, ice sheet modeling using the Ice Sheet System Model (ISSM). Journal of Geophysical Research: Earth Surface, 117(1).

Lea, J. M. 2018. The Google Earth Engine Digitisation Tool (GEEDiT) and the Margin change Quantification Tool (MaQiT) - simple tools for the rapid mapping and quantification of changing Earth surface margins. Earth Surface Dynamics, 6(3), 551-561.

Lenaerts, Jan T. M., Ligtenberg, Stefan R. M., Medley, Brooke, Van de Berg, Willem Jan, Konrad, Hannes, Nicolas, Julien P., Van Wessem, J. Melchior, Trusel, Luke D., Mulvaney, Robert, Tuckwell, Rebecca J., \& et al. 2018. Climate and surface mass balance of coastal West Antarctica resolved by regional climate modelling. Annals of Glaciology, 59(76pt1), 29-41.

Liang, Q. I., Zhou, Chunxia, Howat, Ian A.N.M., Jeong, Seongsu, Liu, Ruixi, \& Chen, Yiming. 2019. Ice flow variations at Polar Record Glacier, East Antarctica. Journal of Glaciology, 65(250), 279-287.

Luckman, Adrian, Elvidge, Andrew, Jansen, Daniela, Kulessa, Bernd, Kuipers Munneke, Peter, King, John, \& Barrand, Nicholas E. 2014. Surface melt and ponding on Larsen C Ice Shelf and the impact of föhn winds. Antarctic Science, $\mathbf{2 6}(6), 625-635$.

Mayewski, P. A., Meredith, M. P., Summerhayes, C. P., Turner, J., Worby, A., Barrett, P. J., Casassa, G., Bertler, N. A.N., Bracegirdle, T., Naveira Garabato, A. C., Bromwich, D., Campbell, H., Hamilton, G. S., Lyons, W. B., Maasch, K. A., Aoki, 
S., Xiao, C., \& Van Ommen, Tas. 2009. State of the antarctic and southern ocean climate system. Reviews of Geophysics, 47(1), 1-38.

McGrath, Daniel, Steffen, Konrad, Rajaram, Harihar, Scambos, Ted, Abdalati, Waleed, \& Rignot, Eric. 2012. Basal crevasses on the Larsen C Ice Shelf, Antarctica: Implications for meltwater ponding and hydrofracture. Geophysical Research Letters, 39(16), 1-6.

Milillo, P., Rignot, E., Rizzoli, P., Scheuchl, B., Mouginot, J., Bueso-Bello, J., \& Prats-Iraola, P. 2019. Heterogeneous retreat and ice melt of thwaites glacier, West Antarctica. Science Advances, 5(1), 1-9.

Morlighem, M., Rignot, E., Seroussi, H., Larour, E., Ben Dhia, H., \& Aubry, D. 2010. Spatial patterns of basal drag inferred using control methods from a fullStokes and simpler models for Pine Island Glacier, West Antarctica. Geophysical Research Letters, $37(14)$.

Morlighem, Mathieu, Rignot, Eric, Binder, Tobias, Blankenship, Donald, Drews, Reinhard, Eagles, Graeme, Eisen, Olaf, Ferraccioli, Fausto, Forsberg, René, Fretwell, Peter, Goel, Vikram, Greenbaum, Jamin S, Gudmundsson, Hilmar, Guo, Jingxue, Helm, Veit, Hofstede, Coen, Howat, Ian, Humbert, Angelika, Jokat, Wilfried, Karlsson, Nanna B, Lee, Won Sang, Matsuoka, Kenichi, Millan, Romain, Mouginot, Jeremie, Paden, John, Pattyn, Frank, Roberts, Jason, Rosier, Sebastian, Ruppel, Antonia, Seroussi, Helene, Smith, Emma C, Steinhage, Daniel, Sun, Bo, van den Broeke, Michiel R, van Ommen, Tas D, van Wessem, Melchior, \& Young, Duncan A. 2020. Deep glacial troughs and stabilizing ridges unveiled beneath the margins of the Antarctic ice sheet. Nature Geoscience, 13(2), 132-137. 
Mouginot, J., Rignot, E., \& Scheuchl, B. 2014. Sustained increase in ice discharge from the Amundsen Sea Embayment, West Antarctica, from 1973 to 2013. Geophysical Research Letters, 41(5), 1576-1584.

Nick, F. M., Van Der Veen, C. J., Vieli, A., \& Benn, D. I. 2010. A physically based calving model applied to marine outlet glaciers and implications for the glacier dynamics. Journal of Glaciology, 56(199), 781-794.

Nick, F. M., Luckman, A., Vieli, A., Van Der Veen, C. J., Van As, D., Van De Wal, R. S.W., Pattyn, F., Hubbard, A. L., \& Floricioiu, D. 2012. The response of Petermann Glacier, Greenland, to large calving events, and its future stability in the context of atmospheric and oceanic warming. Journal of Glaciology, 58(208), 229-239.

Nick, Faezeh M., van der Veen, C. J., \& Oerlemans, J. 2007a. Controls on advance of tidewater glaciers: Results from numerical modeling applied to Columbia Glacier. Journal of Geophysical Research: Earth Surface, 112(3), 1-11.

Nick, Faezeh M., van der Kwast, Johannes, \& Oerlemans, Johannes. 2007b. Simulation of the evolution of Breidamerkurjökull in the late Holocene. Journal of Geophysical Research: Solid Earth, 112(1), 1-12.

Nick, Faezeh M., Vieli, Andreas, Howat, Ian M., \& Joughin, Ian. 2009. Large-scale changes in Greenland outlet glacier dynamics triggered at the terminus. Nature Geoscience, 2(2), 110-114.

Noël, Brice, Jan Van De Berg, Willem, MacHguth, Horst, Lhermitte, Stef, Howat, Ian, Fettweis, Xavier, \& Van Den Broeke, Michiel R. 2016. A daily, 1 km resolu- 
tion data set of downscaled Greenland ice sheet surface mass balance (1958-2015). Cryosphere, 10(5), 2361-2377.

Noh, Myoung-Jong, \& Howat, Ian M. 2015. Automated stereo-photogrammetric DEM generation at high latitudes: Surface Extraction with TIN-based Searchspace Minimization (SETSM) validation and demonstration over glaciated regions. GIScience \& Remote Sensing, 52(2), 198-217.

Paden, J., Li, J., Leuschen, C., Rodriguez-Morales, F., \& Hale, R. 2010. IceBridge MCoRDS L2 Ice Thickness, Version 1.

Paden, J., Li, J., Leuschen, C., Rodriguez-Morales, F., \& Hale, R. 2014. IceBridge MCoRDS L1B Geolocated Radar Echo Strength Profiles, Version 2.

Paolo, F. S., Padman, L., Fricker, H. A., Adusumilli, S., Howard, S., \& Siegfried, M. R. 2018. Response of Pacific-sector Antarctic ice shelves to the El Niño/Southern Oscillation. Nature Geoscience, 11(2), 121-126.

Pȩtlicki, Michał, Sziło, Joanna, MacDonell, Shelley, Vivero, Sebastián, \& Bialik, Robert J. 2017. Recent Deceleration of the Ice Elevation Change of Ecology Glacier (King George Island, Antarctica). Remote Sensing, 9(6).

Pritchard, H. D., \& Vaughan, D. G. 2007. Widespread acceleration of tidewater glaciers on the Antarctic Peninsula. Journal of Geophysical Research: Earth Surface, $\mathbf{1 1 2}(3), 1-10$.

Rebesco, M., Domack, E., Zgur, F., Lavoie, C., Leventer, A., Brachfeld, S., Willmott, V., Halverson, G., Truffer, M., Scambos, T., Smith, J., \& Pettit, E. 2014. Bound- 
ary condition of grounding lines prior to collapse, Larsen-B Ice Shelf, Antarctica. Science AAAS, 345(6202), 1354-1358.

Rignot, E., Casassa, G., Gogineni, P., Krabill, W., Rivera, A., \& Thomas, R. 2004. Accelerated ice discharge from the Antarctic Peninsula following the collapse of Larsen B ice shelf. Geophysical Research Letters, 31(18), 2-5.

Rignot, Eric, \& Jacobs, Stanley S. 2002. Rapid Bottom Melting Widespread near Antarctic Ice Sheet Grounding Lines. Science, 296(5575), 2020-2023.

Rignot, Eric, Bamber, Jonathan L., Van Den Broeke, Michiel R., Davis, Curt, Li, Yonghong, Van De Berg, Willem Jan, \& Van Meijgaard, Erik. 2008. Recent Antarctic ice mass loss from radar interferometry and regional climate modelling. Nature Geoscience, 1(2), 106-110.

Rignot, Eric, Mouginot, Jérémie, Scheuchl, Bernd, Van Den Broeke, Michiel, Van Wessem, Melchior J., \& Morlighem, Mathieu. 2019. Four decades of Antarctic ice sheet mass balance from 1979-2017. Proceedings of the National Academy of Sciences of the United States of America, 116(4), 1095-1103.

Rintoul, Stephen Rich, Silvano, Alessandro, Pena-Molino, Beatriz, van Wijk, Esmee, Rosenberg, Mark, Greenbaum, Jamin Stevens, \& Blankenship, Donald D. 2016. Ocean heat drives rapid basal melt of the Totten Ice Shelf. Science Advances, 2(12).

Robel, Alexander A., \& Banwell, Alison F. 2019. A Speed Limit on Ice Shelf Collapse Through Hydrofracture. Geophysical Research Letters, 46(21), 12092-12100. 
Roberts, Jason, Galton-Fenzi, Benjamin K., Paolo, Fernando S., Donnelly, Claire, Gwyther, David E., Padman, Laurie, Young, Duncan, Warner, Roland, Greenbaum, Jamin, Fricker, Helen A., Payne, Antony J., Cornford, Stephen, Le Brocq, Anne, van Ommen, Tas, Blankenship, Don, \& Siegert, Martin J. 2018. Ocean forced variability of Totten Glacier mass loss. Geological Society, London, Special Publications, 461(1), 175-186.

Scambos, Ted A., Hulbe, Christina, Fahnestock, Mark, \& Bohlander, Jennifer. 2000. The link between climate warming and break-up of ice shelves in the Antarctic Peninsula. Journal of Glaciology, 46(154), 516-530.

Schmidtko, Sunke, Heywood, Karen J., Thompson, Andrew F., \& Aoki, Shigeru. 2014. Multidecadal warming of Antarctic waters. Science, 346(6214), 1227-1231.

Schoof, Christian. 2007. Ice sheet grounding line dynamics: Steady states, stability, and hysteresis. Journal of Geophysical Research: Earth Surface, 112(F3).

Seehaus, Thorsten, Marinsek, Sebastián, Helm, Veit, Skvarca, Pedro, \& Braun, Matthias. 2015. Changes in ice dynamics, elevation and mass discharge of Dinsmoor-Bombardier-Edgeworth glacier system, Antarctic Peninsula. Earth and Planetary Science Letters, 427, 125-135.

Seroussi, H., Nakayama, Y., Larour, E., Menemenlis, D., Morlighem, M., Rignot, E., \& Khazendar, A. 2017. Continued retreat of Thwaites Glacier, West Antarctica, controlled by bed topography and ocean circulation. Geophysical Research Letters, 44(12), 6191-6199.

Shean, David E., Alexandrov, Oleg, Moratto, Zachary M., Smith, Benjamin E., 
Joughin, Ian R., Porter, Claire, \& Morin, Paul. 2016. An automated, open-source pipeline for mass production of digital elevation models (DEMs) from very-highresolution commercial stereo satellite imagery. ISPRS Journal of Photogrammetry and Remote Sensing, 116, 101-117.

Shepherd, Andrew, Fricker, Helen Amanda, \& Farrell, Sinead Louise. 2018. Trends and connections across the Antarctic cryosphere. Nature, 558(7709), 223-232.

Shuman, Christopher A., Berthier, Etienne, \& Scambos, Ted A. 2011. 2001-2009 elevation and mass losses in the Larsen A and B embayments, Antarctic Peninsula. Journal of Glaciology, 57(204), 737-754.

Siegert, Martin, Atkinson, Angus, Banwell, Alison, Brandon, Mark, Convey, Peter, Davies, Bethan, Downie, Rod, Edwards, Tamsin, Hubbard, Bryn, Marshall, Gareth, Rogelj, Joeri, Rumble, Jane, Stroeve, Julienne, \& Vaughan, David. 2019. The Antarctic Peninsula under a $1.5^{\circ} \mathrm{C}$ global warming scenario. Frontiers in Environmental Science, $7(\mathrm{JUN}), 1-7$.

Strass, Volker H., Rohardt, Gerd, Kanzow, Torsten, Hoppema, Mario, \& Boebel, Olaf. 2020. Multidecadal warming and density loss in the Deep Weddell Sea, Antarctica. Journal of Climate, 33(22), 9863-9881.

Trusel, Luke D., Frey, Karen E., Das, Sarah B., Karnauskas, Kristopher B., Kuipers Munneke, Peter, Van Meijgaard, Erik, \& Van Den Broeke, Michiel R. 2015. Divergent trajectories of Antarctic surface melt under two twenty-first-century climate scenarios. Nature Geoscience, 8(12), 927-932.

Tuckett, Peter A., Ely, Jeremy C., Sole, Andrew J., Livingstone, Stephen J., Davi- 
son, Benjamin J., Melchior van Wessem, J., \& Howard, Joshua. 2019. Rapid accelerations of Antarctic Peninsula outlet glaciers driven by surface melt. Nature Communications, 10(1), 1-8.

van den Broeke, Michiel. 2005. Strong surface melting preceded collapse of Antarctic Peninsula ice shelf. Geophysical Research Letters, 32(12).

Van Wessem, J. M., Ligtenberg, S. R.M., Reijmer, C. H., Van De Berg, W. J., Van Den Broeke, M. R., Barrand, N. E., Thomas, E. R., Turner, J., Wuite, J., Scambos, T. A., \& Van Meijgaard, E. 2016. The modelled surface mass balance of the Antarctic Peninsula at $5.5^{-} \mathrm{km}$ horizontal resolution. Cryosphere, 10(1), $271-285$.

Vaughan, David G. 2006. Recent trends in melting conditions on the Antarctic Peninsula and their implications for ice-sheet mass balance and sea level. Arctic, Antarctic, and Alpine Research, 38(1), 147-152.

Vieli, Andreas, \& Nick, Faezeh M. 2011. Understanding and Modelling Rapid Dynamic Changes of Tidewater Outlet Glaciers: Issues and Implications. Surveys in Geophysics, 32(4-5), 437-458.

Vieli, Andreas, Funk, Martin, \& Blatter, Heinz. 2001. Flow dynamics of tidewater glaciers: a numerical modelling approach. Journal of Glaciology, 47(159), 595-606.

Vieli, Andreas, Jania, Jacek, \& Kolondra, Lezek. 2002. The retreat of a tidewater glacier: observations and model calculations on Hansbreen, Spitsbergen. Journal of Glaciology, 48(163), 592-600. 
Walker, C. C., \& Gardner, A. S. 2017. Rapid drawdown of Antarctica's Wordie Ice Shelf glaciers in response to ENSO/Southern Annular Mode-driven warming in the Southern Ocean. Earth and Planetary Science Letters, 476, 100-110. 